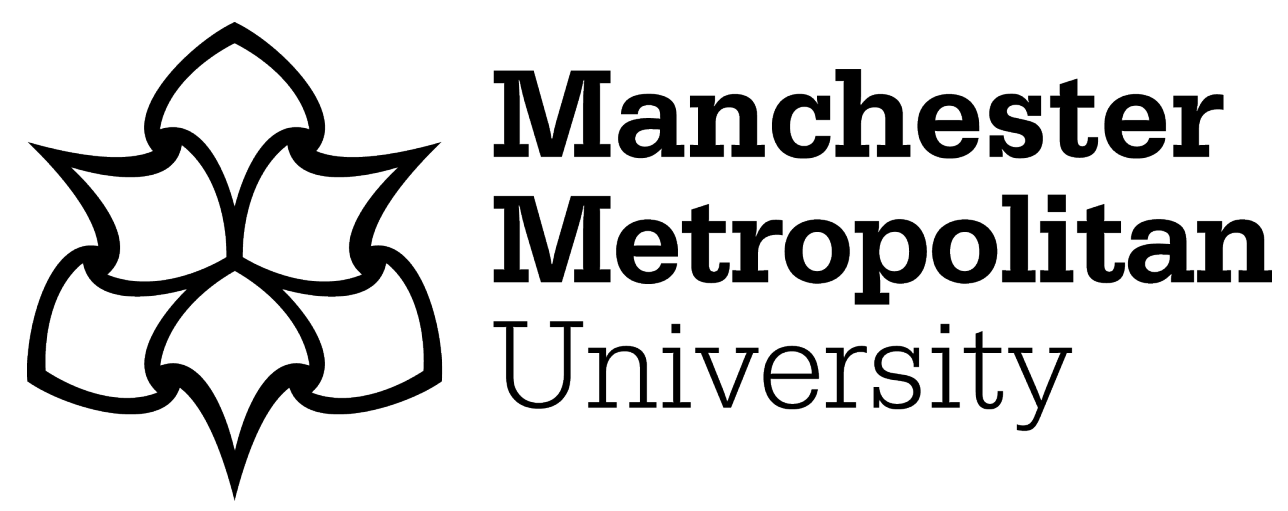

Ashnai, B, Smirnova, M, Henneberg, SC and Naudé, P (2019) Dyadic Operationalization in Business Relationships: The Empirical Example of MarketingPurchasing Collaboration. Journal of Business-to-Business Marketing, 26 (1). pp. 19-42. ISSN 1051-712X

Downloaded from: https://e-space.mmu.ac.uk/622847/

Version: Accepted Version

Publisher: Taylor \& Francis

DOI: https://doi.org/10.1080/1051712X.2019.1565134

Please cite the published version 


\title{
Dyadic operationalization in business relationships: The empirical example of marketing-purchasing collaboration
}

Revised Submission Journal of Business-to-Business Marketing, October 2017

\author{
Author 1 (Corresponding author) \\ Name: Bahar Ashnai \\ Academic Degree: Ph.D., University of Manchester, UK \\ Professional Title: Associate Professor \\ Affiliation: Professional Sales Department, Cotsakos College of Business, William Paterson \\ University of New Jersey, USA \\ Mailing Address: Professional Sales Department, Cotsakos College of Business, William \\ Paterson University, 1600 Valley Road, Wayne, NJ 07470, USA \\ Email: $\underline{\text { ashnaib@wpunj.edu }}$
}

\section{Author 2}

Name: Maria Smirnova

Academic Degree: Ph.D., Saint Petersburg State University, Russia

Professional Title: Associate Professor, Head of Marketing Department

Affiliation: Graduate School of Management, St Petersburg State University, Russia

Mailing Address: Graduate School of Management, St Petersburg State University, St.

Petersburg, 199004, Russia

Email: smirnova@gsom.pu.ru

\section{Author 3}

Name: Stephan C. Henneberg

Academic Degree: Ph.D., University of Cambridge, UK

Professional Title: Chair Professor of Marketing and Strategy

Affiliation: Business Ecosystems Research Group, School of Business and Management, Queen Mary University of London, London, UK

Mailing Address: School of Business and Management, Queen Mary University of London, Bancroft Building, Mile End Road, London E1 4NS, UK

Email: s.henneberg@qmul.ac.uk

\section{Author 4}

Name: Peter Naudé

Academic Degree: Ph.D., University of Manchester, UK

Professional Title: Professor

Affiliation: Manchester Metropolitan Business School, Manchester, UK

Mailing Address: Manchester Metropolitan University, All Saints Campus, Oxford Road, Manchester, M15 6BH, UK

Affiliation: Discipline of Marketing, Sydney University, Australia

Email: p.naude@mmu.ac.uk 


\section{Acknowledgement:}

The Saint Petersburg State University's research support (project fund \#16.23.1846.2015) is gratefully appreciated. 


\title{
Dyadic operationalization in business relationships: The empirical example of marketing-purchasing collaboration
}

\author{
Structured Abstract
}

Purpose: The purpose of this paper is to explore whether dyadic operationalization within business relationships is feasible and sensible in a rigorous way. It aims to introduce quantitative operationalizations of business relationship characteristics from both monadic and dyadic datasets, and to introduce aggregation techniques for utilizing the richness of dyadic data. It compares and contrasts the effectiveness of different techniques in terms of explaining business relationship phenomena, using an empirical exemplification.

Methodology/Approach: The paper reviews the relevant literature and summarizes various dyadic operationalization and aggregation approaches. It furthermore illustrates such operationalization and aggregation by utilizing an empirical example. A nomological model of marketing-purchasing collaboration is developed and tested based upon internal dyadic data. Using alternative model comparisons, we contrast several different ways of operationalizing dyadic data (combined, dyadic, and dyadic with asymmetry), and compare the outcomes utilizing structural equation modeling.

Findings: The study of business relationships typically makes use of a variety of data types, ranging from simple monadic to perceived dyadic, through to rigorous dyadic data. The various aggregation methods include value, asymmetry, and directional asymmetry approaches. Pertinent sub-constructs are developed based on these aggregation methods and relevant hypotheses incorporating and reflecting on the role of the sub-constructs are suggested to develop a more meaningful and rich quantitative analysis of business relationship phenomena. 
Research Implications: This paper explores the different ways in which data assessing the relationship between two interacting parties can be operationalized. Dyadic operationalization within the context of business relationships is sensible and recommended. Researchers can adopt approaches to conduct dyadic data operationalization including data collection methods such as perceived dyadic and rigorous dyadic. They should benefit from rich dyadic aggregation approaches such as value, asymmetry, and directional asymmetry, noting the strengths and weaknesses of each approach discussed in this paper.

Practical Implications: Businesses are recommended to increase customer orientation and marketing-purchasing interaction to improve collaboration between marketing and purchasing departments and thus their overall performance. Businesses should also develop an alignment between the collaboration perceptions of the involved departments, and note that perceptual symmetry improves collaboration. Perception matching in a dyadic relationship plays a role in enhancing the overall firm performance. Managers should note that all involved parties' perspectives are to be included to ensure a positive and collaborative liaison. An allencompassing attitude and perspective (as opposed to an asymmetric, unbalanced one) ensures an effective relationship.

Originality/Value/Contribution of the paper: The contribution of the research lies in outlining different ways to accomplish more insightful analytics regarding data operationalization, and their different strengths and weaknesses in terms of explaining relationship characteristics, and therefore enriches research on business relationships by making better sense of quantitative dyadic data. 


\section{Keywords}

Business relationships, Dyadic operationalization, Dyadic data aggregation, Marketingpurchasing collaboration 


\section{Dyadic operationalization in business relationships: The empirical example of marketing-purchasing collaboration}

\section{Introduction}

In business relationships, a number of different facets limit companies' operational choices and strategic options with regard to how they act. These include the perceptions and anticipations of the exchange partners' attitudes such as trust (De Ruyter et al. 2001) and loyalty (Auh and Shih 2005), as well as the exchange partners' behaviors, such as cooperation (Tjosvold and Wong 1994), involvement (Macht 2011), and willingness to collaborate (Kahn and Mentzer 1998). Such business relationships must exist internally within an organizational entity (e.g. the interactions between marketing and sales departments) (Homburg and Jensen 2007; Le MeunierFitzHugh and Piercy 2007) and externally between two entities (e.g. the relationship between a supplier and customer company) (Anderson et al. 1994). As such, the relationship itself becomes an important unit of analysis, i.e. the 'in-betweenness' or interstitial space between firms or organizational functions within a dyad represents the focal research phenomenon, and not the actions of individual parties themselves (Dwyer et al. 1987; Barnes et al. 2005). Taking this perspective, quantitative research on business relationships requires methods and techniques to quantify business relationships, with clear consideration of the complexities of these phenomena, given the involvement of more than one party in the relationship. It has therefore been widely accepted, especially in the area of business-to-business marketing and supply chain management, that it is more appropriate to look at the business relationship and its characteristics within a dyadic structure (Anderson et al. 1994; Svensson 2004), rather than within a monadic structure using a focal party perspective. 
However, it is unclear from a methodological point of view how to quantitatively operationalize dyadic data. Our paper thus tackles the question: How best is data on dyadic business relationships operationalized and aggregated? We explore the viability of dyadic analyses of business relationships within a quantitative research design, in order to capture the rich texture of the interactions between parties, focusing on the 'in-betweenness' characteristics of relationships. There are a number of studies that examine business exchanges using quantitative dyadic data (e.g. Dyer 1996; Rodriguez and Wilson 2002; Svensson 2004; Blesa and Bigné 2005; Palmatier et al. 2007; Kumar et al. 2011; Bstieler et al. 2017). These tend though to focus mainly on two advantages of collecting such data from both perspectives. The first is to minimize common method bias using both levers of multiple informants and units of observation to capture distinct constructs, such as the employee's satisfaction and the customer's satisfaction (see Palmatier et al. 2007; Joshi 2009; Boukis and Gounaris 2015). The second is the ability to examine the two parties' differences such as the buyer's versus the seller's characteristics (see Rodriguez and Wilson 2002; Whipple et al. 2015). The few studies that do capture dyadic data often examine them conceptually and analytically as different variables, for instance customer orientation perceived by both the seller and by the buyer (Brach et al. 2015). There are only a small number of studies that operationalize and aggregate data in a dyadic way (such as Deshpandé et al. 1993, 2000; Straub et al. 2004; Klein et al. 2007).

This paper provides an overview of different ways to operationalize dyadic data in order to capture the characteristics of the relationship partners and their (inter)dependencies and contingencies on each other. This includes a review of quantitative data collection from a monadic through to a dyadic approach. In addition, it introduces different ways of aggregating dyadic data, which is under-developed and called for in business marketing research (Dess et al. 
1993). It also develops and tests an illustrative model that includes internal dyadic sub-constructs by examining marketing-purchasing interaction and collaboration. This study extends the body of the literature that calls for a better understanding of dyadic relationships and a more appropriate choice of the unit of analysis, unit of observation, and operationalization in business relationships (Rousseau 1985; Johnston and Lewin 1996), and thereby contributes to the understanding of managing business relationships by providing insights into dyadic relationship dynamics (Elo et al. 2015).

This article will proceed as follows: initially, an overview of existing types of quantitative operationalizations of dyadic data is provided. These are categorized by the different units of analysis underlying such operationalizations. We then utilize an existing empirical dataset to exemplify the use of monadic versus dyadic data and compare the findings. A model is used which examines the impact of customer orientation and the interactions between departments (specifically marketing and purchasing) as collaboration antecedents, and which analyses the direct impact of the marketing-purchasing collaboration on business performance. The model is tested on a sample of 148 industrial companies in Russia with two key respondents in each firm, incorporating the purchasing and the marketing perspective. A conclusion as well as a discussion of the limitations and implications follows.

\section{Dyadic operationalization}

Reviews of the business-to-business marketing and business relationship literature highlight that studies of these relationships are more appropriate when using a dyadic approach (Reid and Plank 2000; Barnes et al. 2005). Complex organizational interactions are better understood via a dyadic, or so called 'systems' approach (Johnston and Bonoma 1981). The business marketing 
literature calls for empirical examination, especially with regard to the dyadic aspects of business relationships (Johnston and Lewin 1996). Many phenomena in business marketing and supply chain management, but also in organizational studies, relate to interactions between two parties, i.e. a dyad. However, it remains somewhat unclear how a quantitative operationalization of a dyadic phenomenon should be done, be it based on an internal or an external dyad (i.e. regarding an intra-organizational or an inter-organizational relationship, respectively). This challenge represents the starting point for the development of types of quantitative operationalizations that differ with regard to their units of analysis. In business and marketing studies, the focus of conceptualizations can be on an individual actor, a group as an organizational entity such as a team, a company or an industry. Furthermore, these actors are connected to dyads and networks (Håkansson and Snehota 1989; Klein et al. 1994; Gadde 2004; Gummesson 2010; Simangunsong 2013). Conceptualizations can have more than one level. An appropriate and matching level of theory, level of measurement and level of analysis are required when designing and discussing research studies: The level of theory describes the target (e.g. individual, group, organization, relationship or network) that the researcher aims to investigate. It is the level at which generalization is made. The level of observation describes the actual source of the data. The level of statistical analysis describes the treatment of the data during statistical procedures (Rousseau 1985; Klein et al. 1994). For instance, either individual dyadic business relationships or the network of business relationships can be the focus of the study (Dyer and Singh 1998).

\subsection{Data types in business relationship research}

An illustrative overview of the existing quantitative literature on business relationships is used to exemplify the resulting three different types of operationalizations. In general, these types can be distinguished by their progression from a purely monadic point of view (i.e. focal 
party-centered) to a rigorous dyadic point of view (i.e. relationship-centered). We also discuss the unit of analysis and the unit of observation for each type.

2.1.1 Monadic operationalization (Unit of analysis: monad; unit of observation: focal party)

In monadic data collection one party involved in the business relationship will act as the sole unit of observation, representing the focal party. The operationalization of the characteristic under study is executed by quantifying to what degree the focal party evaluates that characteristic. For an illustrative purpose we use 'collaboration' (see figure 1). In this case, in order to quantify the level of collaboration in the relationship between Actor A and Actor B, Actor A (the focal party) is asked to what extent they collaborate closely in the relationship with Actor B. Previous studies have used this form of operationalization to quantify constructs such as trust and commitment (Morgan and Hunt 1994), or integration and control (Mohr et al. 1996). Many studies of business relationships are based on this approach (e.g. Cavusgil et al. 2004; Alvarez et al. 2010; Cao and Zhang 2011; Liu et al. 2013).

\section{--- Insert Figure 1 about Here ---}

2.1.2 Perceived dyadic operationalization (Unit of analysis: dyad; unit of observation: focal party)

A perceived dyad focuses on the relationship between two parties as the unit of analysis. This captures the interaction that is a product of behaviors and attitudes of the parties involved. However, the characteristics are measured by the data collected solely from one party or actor. This focal party in our example (illustrated in figure 1) is Actor A. In this case two monadic perspectives are compared which are the perspective of the Actor A's own perceptions and also his/her perception of Actor B's perception. Thus, Actor A (the focal party) is asked both to what 
extent A collaborates closely in the relationship with Actor B, as well as how closely they believe $\mathrm{B}$ is collaborating with $\mathrm{A}$ in that relationship.

Previously this method has been used for example by Mohr and colleagues (1996) to capture collaborative communication. In their study the dealer and the manufacturer's communication frequency were used (both assessed by the dealer), and overall relationship communication was calculated using both measures. In other cases, the buyer was asked to evaluate both actors' (the buyer and the seller) dependence on the other party (for example, see Kumar et al. 1995a; Jap and Ganesan 2000). Heide (1994) also used this method to measure (buyer and supplier) dependence and to capture symmetric and unilateral dependence. He tested the hypothesis regarding symmetric dependence by using the interaction effect (of both sides' dependence) on the dependent variable.

The component scores are collected from one party (i.e. the unit of observation). As such, the perceived dyadic operationalization represents a possible substitute for rigorous dyadic data captured from both involved parties, for instance in cases where collecting data from both interaction partners is too difficult but a dyadic operationalization is deemed necessary.

\subsubsection{Dyadic operationalization (Unit of analysis: dyad; unit of observation: dyad)}

The focus of a rigorous dyadic operationalization is on the characteristics of a business relationship incorporating both sides' evaluation of the phenomenon under study. In our illustrative example of collaboration (shown in figure 1) the data collection involves measuring each party's perspective regarding the characteristic monadically. Therefore, each actor is asked the same question about the same ('matched') business relationship. The collected scores are compared and contrasted to produce the aggregated score representing the dyad as a whole. In the collaboration example, both actors are asked to assess the extent to which they collaborate 
closely with the other party. Previous studies employing this method, using the dyad as unit of observation as well as the unit of analysis, include internal dyads, with data collected from a pair of marketing executives (Deshpandé et al. 1993) and also external dyads measuring constructs such as market orientation and satisfaction in business relationships (Blesa and Bigné 2005). However, such considerations do not provide any operationalization of the 'in-betweenness' characteristics of the dyadic data, which is discussed in the aggregation types in the following section of this paper.

\subsection{Aggregation types in business relationship research}

As with all dyadic and perceived dyadic operationalizations, two (or more) datapoints regarding a variable or construct need to be aggregated. The final construct score can be calculated in three different ways, as a value, or by using asymmetry or directional asymmetry.

\subsubsection{Dyadic value sub-construct}

The value sub-construct is calculated as the average of the scores. It is the simplest way of aggregating dyadic scores and incorporating them in a measure that captures the 'inbetweenness' of the dyad. This form of aggregation has been used frequently within the literature (Deshpandé et al. 1993, 2000; Straub et al. 2004; Klein et al. 2007). In the simplest form an overall dyadic measure (e.g. mean) is calculated. For instance, the mean of the scores collected from two marketing managers of a focal company has been calculated in order to aggregate a dyadic level measurement (Deshpandé et al. 1993), which represents an internal dyadic value sub-construct. Alternatively, in cases of buyer and seller interactions, the data can be collected from both seller and buyer, which creates an external dyadic value sub-construct. It is also possible to weight the scores, for instance by weights reflecting each respondent's level of expertise regarding the questions asked, or their experience levels. For example, Van Bruggen et 
al. (2002) use weighting and aggregating scores for analyzing student data based on simulation techniques.

\subsubsection{Dyadic asymmetry sub-construct}

The asymmetry sub-construct allows the researcher to move beyond the use of basic scores, examining the extent to which these scores are asymmetric or symmetric. Different techniques can be used for this purpose. Previous researchers have incorporated this approach to determine dyadic scores (Anderson and Narus 1990; Kumar et al. 1995a; Jap and Ganesan 2000; Gilliland and Bello 2002; Straub et al. 2004; Klein et al. 2007). The most straight-forward way to achieve an asymmetry sub-construct is subtracting the lower from the higher score (Anderson and Narus 1990; Kumar et al. 1995a; Jap and Ganesan 2000; Gilliland and Bello 2002). This implies that scores of 1 and 5 on a 7-point Likert scale result in a relatively high asymmetric score of 4, whereas if both respondents' evaluations are 3 , it results in a perfectly symmetrical score of 0 . If the researcher were to rely solely on the value sub-construct (i.e. mean), these two scenarios produce the same score of 3 , missing valuable information inherent in the dyadic data. Therefore, this additional sub-construct can play a major role preserving the richness of dyadic data.

Furthermore, previous research has used the technique of dividing the lower score by the higher score for incorporating asymmetry (Straub et al. 2004; Klein et al. 2007) as well as other techniques such as using t-test analysis and correlations (Buijzen and Valkenburg 2003; Svensson 2004; Holmlund-Rytkönen and Strandvik 2005; Boukis and Gounaris 2015), and testing the interaction effect (Heide 1994).

\subsubsection{Dyadic directional asymmetry sub-construct}

To further enrich the aggregation technique and incorporate information provided by dyadic data, the directionality of the difference can be investigated and used. This sub-construct reveals 
which actor has evaluated the construct as being higher or lower. For this purpose the scores collected from one actor (e.g. purchasing manager A) and the scores collected from the other actor (e.g. marketing manager B) are compared, to examine whether score A > score B or score $\mathrm{B}>$ score A. The sample is divided accordingly and tested running t-test analyses (DelVecchio 1996). Another method is to use the absolute value (e.g. the difference, which is always positive) and dummy variables to identify whether there has been a situation in which $(00)$ score $\mathrm{A}=$ score B, (01) score A > score B, or (10) score B > score A (Kumar et al. 1995a).

Previous studies are summarized in a table in Appendix 1. The appendix offers a structured presentation of the studies that are cited in this paper in terms of classifying monadic, perceived dyadic, and dyadic data collection. The table also summarizes the references' theory focus, the unit of analysis, measurement and analysis, monadic versus dyadic versus network conceptualization, internal versus external relationship, and dyadic operationalization.

\section{Exemplifying dyadic operationalization with empirical data}

In order to exemplify the use of the different operationalizations and aggregations discussed above, we use nested models on the role of marketing-purchasing collaboration, examining its antecedents (marketing-purchasing interaction, and customer orientation) and consequences (business performance), in the context of an already published study. In the following paragraphs the model and its underlying hypotheses are briefly discussed; for a more detailed discussion and derivation of the underlying model see Smirnova and colleagues (2011). We use the first four hypotheses from Smirnova and colleagues in Models 1a to 1c. We also use additional hypotheses, discussed in the following section, to complete the empirical example (Models 2 and $3)$. 


\subsection{Monadic operationalization}

The model investigates the role of inter-functional collaboration between marketing and purchasing functions in companies. Smirnova and colleagues' (2011) underlying model uses Kahn and Mentzer (1996) approach to interdepartmental integration, which specifically differentiates between the two aspects of interdepartmental interaction and interdepartmental collaboration. This perspective is further advocated by empirical research identifying interaction and collaboration as distinct constructs (Kahn and Mentzer 1998). Inter-functional collaboration is considered as a measure of the internal alignment and partnership between departments in the firm. Marketing-purchasing collaboration contributes to the creation of sustainable advantages via improved external partnerships and facilitating demand chain integration (Kahn and Mentzer 1996; Jüttner et al. 2007). It also improves the firm's strategic market sensing capabilities (Day 1994; Foley and Fahy 2004). Thus, it is suggested that marketing-purchasing collaboration impacts positively on business performance (Hypothesis 1). Interaction is an important part of business relationships, as well as interdepartmental activities (Ruekert and Walker 1987) and has been identified as a key antecedent of collaboration (Cadogan et al. 2005). Therefore, it is posited that marketing-purchasing interaction impacts positively on marketing-purchasing collaboration (Hypothesis 2). Understanding demand, a task that is primarily done by the marketing function, has a key role in aligning departments and activities within the firm (Day 1990; Kohli and Jaworski 1990; Jaworski and Kohli 1993). It has been argued that the integration of departments is to a large extent the responsibility of customer-facing units (Kahn and Mentzer 1996). In this context it is key to disseminate knowledge about demand, i.e. market and customer-related information among the departments (Nonaka et al. 1996). It is therefore hypothesized that customer orientation impacts positively on marketing-purchasing 
collaboration (Hypothesis 3). Dissemination of information and intelligence across firms' functions represents an integral component of market and customer orientation (Slater and Narver 1994; Maltz and Kohli 1996). To achieve such customer knowledge, the purchasing department as one of the major functions of the firm, needs to have interaction with the owner of this intelligence, i.e. the marketing department. Therefore, it is suggested that marketingpurchasing interaction impacts positively on customer orientation (Hypothesis 4). These four basic hypotheses form the main nomological model (Model 1a).

\subsection{Dyadic operationalization (value and asymmetry)}

For Model 2 the data regarding each item from both respondents is combined to form a match-paired dyadic score. As both respondents from the relevant functions are located within the same organization, it is their internal business relationship that makes up the research phenomenon, therefore resembling an internal dyad. Therefore, Model 2 examines the same set of hypotheses as Model 1a, while using the dyadic scores. Finally, Model 3 adds a dyadic asymmetry operationalization: it is not only the scores themselves that are of interest, but also the degree to which these scores differ or overlap. Further hypotheses are suggested involving this new sub-construct: Marketing-purchasing collaboration asymmetry reflects the degree to which perceptions of marketing and purchasing departments are different. This perceptual difference (asymmetry) regarding relationship characteristics is expected to have a deleterious effect on the quality of the relationship. Previous studies have discussed similar effects: Symmetry between perceptions of the two focal parties in the dyad, for instance regarding both attitudinal (e.g. trust) and behavioral (e.g. relationship-specific investments and information flows) characteristics, has a positive impact on the relationship (Straub et al. 2004; Klein et al. 2007). A lack of significant association between the perceptions of the two focal parties of the dyad results in the 
vulnerability of the relationship (Svensson 2004). Perceptual asymmetry of the marketingpurchasing collaboration captures the mismatch between perceptions of the marketing and purchasing departments regarding collaboration. While a perceptual match enhances relationship qualities, a perceptual mismatch diminishes the overall collaboration (Bucklin and Sengupta 1993; Esper et al. 2010; Kumar et al. 2011), Therefore, it is suggested that marketing-purchasing collaboration dyadic asymmetry impacts negatively on marketing-purchasing collaboration (Hypothesis 5).

A key element for aligning perceptions of a relationship and reducing perceptual differences is proper communication (Mohr and Nevin 1990) which underpins the interaction between parties (Nonaka 1994; Tsai 2001; Ford et al. 2011). Information flow between demand-focused departments (i.e. marketing) and supply-focused departments (i.e. purchasing) enables interdepartmental integration and reduces inter-functional mismatch (Esper et al. 2010). The marketing-purchasing interaction exists through information exchange that instills collective goals, strengthens the relationship between departments and increases interdepartmental collaboration symmetry (i.e. decreases its asymmetry). Thus, it is posited that marketingpurchasing interaction impacts negatively on marketing-purchasing collaboration dyadic asymmetry (Hypothesis 6). Model 3 consists therefore of all six hypotheses.

\subsection{Data collection and sample description}

As outlined in Smirnova et al. (2011), the data was collected through structured interviews with key respondents in Russian industrial firms that agreed to provide at least two respondents willing to take part in the study. Items from existing scales were translated and back-translated in order to confirm the accuracy of translation and equivalence of meaning. A copy of the research instrument is presented in Appendix 2. Overall, 502 industrial firms from 34 regions in Russia 
were contacted, from which 186 firms agreed to take part (resulting in 186 pairs of responses). Data collection in Russia as an emerging economy is characterized by an increased resistance of firms to take part in research studies. The perceived risks of information disclosure have been discussed in the existing literature (e.g. Salmi 2004). The reasons mentioned by the firms that refused to take part in the study included low readiness to devote time to filling in the questionnaire, low readiness to disclose information, or not being able to assign a responsible person for filling in the questionnaire. Another reason relates to the geographic diversity of the targeted regions and location of the university that conducted the data collection.

Based on knowledge levels and position, some respondents were screened out, resulting in 148 firms, which provided internal dyadic responses suitable to conduct further analyses (i.e. a dyadic response rate of $29 \%$ ). Selecting the respondents was crucial to identify well-informed respondents for dyadic data collection. To verify the respondents' knowledgeability, they were asked to identify how competent they considered themselves regarding the questions they were asked. The result of an average of 4.7 on a 5-point Likert scale (5 being 'very competent') indicated that the respondents had the relevant expertise and knowledge.

The sampling procedure was stratified by region, industry and size of the firm. Key respondents identified in each company were mostly top management, especially heads of marketing or purchasing. They included CEO, CMO, or other senior marketing and procurement specialists. Two respondents per company were used, one covering the marketing and the other the purchasing perspective of the company. Using multiple respondents in the same company minimizes common method bias (Podsakoff et al. 2003). The average age of marketing respondents was 42.4 years, while for purchasing respondents the average age was 41.2 years. In total $84 \%$ of firms in the sample produce predominantly goods, and $16 \%$ services. 


\subsection{Operationalization and data analysis}

Measurement of all the constructs used in the model was based on existing scales in the literature (MacKenzie et al. 2005; Diamantopoulos and Siguaw 2006). See appendix 2 for a list of scales. The customer orientation construct was measured using scales suggested by Narver and Slater (1990). Marketing-purchasing interaction and marketing-purchasing collaboration scales were based on Kahn and Mentzer (1998). These two constructs are distinguished in terms of operationalization in line with their conceptualization. Marketing-purchasing interaction accounts for various types of communication between the departments, including meetings, committees/task forces, phone conversations and emails. Marketing-purchasing collaboration is the degree to which there exists a perception of collaboration, aiming at joint goals, sharing mutual understanding, ideas and resources, which typifies working as a joint team. Business performance was measured on three dimensions: growth of comparative market share, sales growth, and business profitability (Vorhies and Harker 2000). Customer orientation, marketingpurchasing interaction and collaboration questions were measured on a five-point Likert scale anchored in 'completely disagree (1); completely agree (5)'; the questions on business performance were measured on five-point bi-polar scales, and anchored in 'much worse (-2); much better (2)', asking the respondents to compare their own business performance with that of competitors (see appendix 2).

In line with the original study (Smirnova et al. 2011), in Model 1a the data collected from purchasing managers was used to capture customer orientation and marketing-purchasing interaction. Data collected from marketing managers was used to measure marketing-purchasing collaboration and business performance. This allowed us to measure marketing department's efforts using the other party (purchasing departments)'s perspective while measuring the 
constructs that are mainly the consequences of the efforts of the marketing department from the marketing department itself. Therefore, Model 1a is based on a combined dataset.

Dyadic value operationalization, as defined above, captures the overall magnitude of the relevant construct within the dyad. In our example we operationalize the dyadic value as the average of the two scores collected from the marketing and purchasing departments (i.e. unweighted). This is the most common aggregation method for operationalizing dyadic data for marketing-related research, but also in other streams of research looking into dyadic relationships, for instance in studying parent-child relationships (Buijzen and Valkenburg 2003). This dyadic value operationalization is used for all constructs in the model (i.e. customer orientation, marketing-purchasing interaction, marketing-purchasing collaboration and business performance). This operationalization is used when testing hypotheses 1, 2, 3, and 4 in Model 2 (as mentioned above, these hypotheses are the same as in Model 1a), thus Model 2 is based on a dyadic dataset.

Dyadic asymmetry operationalization is computed in addition to the dyadic value operationalization. This variable captures the extent to which match-paired dyadic scores differ or overlap. The deduction technique, using a distinct sub-construct (asymmetry), is chosen to focus on the dyadic operationalization. Therefore, the higher score is deducted from the lower score. An asymmetry operationalization is used for marketing-purchasing collaboration, which is the focal construct in the model. Dyadic asymmetry is included in Model 3. Therefore, Model 3 uses a dyadic dataset with asymmetry.

Using AMOS 7.0, we ran a confirmatory factor analysis (CFA) for these models and datasets (combined dataset, dyadic dataset, and dyadic dataset with asymmetry), resulting in acceptable fit for the alternative models (Jöreskog and Sörbom 1988; Kline 2005). For the combined dataset 
(Model 1a) the model estimates are: Chi square/df $=1.098(\mathrm{p}=0.268), \mathrm{RMR}=0.043, \mathrm{GFI}=$ 0.932, CFI $=0.994$, RMSEA $=0.026(\mathrm{p}=0.895)$; the estimates for the dyadic dataset $($ Model 2): Chi square/df $=1.227(\mathrm{p}=0.094), \mathrm{RMR}=0.041, \mathrm{GFI}=0.929, \mathrm{CFI}=0.989, \mathrm{RMSEA}=0.039$ $(\mathrm{p}=0.727)$; and the dyadic dataset with asymmetry (Model 3): Chi square $/ \mathrm{df}=1.403(\mathrm{p}=0.002)$, $\mathrm{RMR}=0.040, \mathrm{GFI}=0.894, \mathrm{CFI}=0.968, \mathrm{RMSEA}=0.052(\mathrm{p}=0.400)$.

Reliability and unidimensionality of all scales were tested (Fornell and Larcker 1981; Anderson and Gerbing 1988). We computed the reliability measures in three contexts: combined, dyadic, and dyadic with asymmetry, used for testing Model 1a, 2 and 3, respectively. Our combined dataset used data by the two different respondents (marketing and purchasing side) for various constructs. In this dataset, the customer orientation and marketing-purchasing interaction were measured by using the purchasing-side respondents, while marketing-purchasing collaboration and business performance were measured by the respondents from the marketing side. Table 1 provides the measurement statistics for this dataset and table 2 presents the AVEs (average variance extracted) and squared construct correlation matrix. In our next dataset (dyadic) we used value operationalization, thus calculating an overall mean measure for each of the items. In table 1 the measurement items for this dataset are summarized as well. For the last dataset (dyadic with asymmetry), in addition to the dyadic measures discussed in the second dataset, an asymmetry operationalization of the central construct (i.e. marketing-purchasing collaboration) was included. Table 1 presents the measurement statistics for this dataset as well. Tables 3 and 4 provide the descriptive statistics, as well as a presentation of the AVEs and squared construct correlation matrix pertaining to second (dyadic) and third (dyadic with asymmetry) datasets, respectively.

--- Insert Table 1 about Here --- 
Regarding the non-asymmetry items, all loadings are above 0.70 , except for one item ('Emails' for marketing-purchasing interaction: 0.60 in the combined dataset, and 0.51 in the dyadic and dyadic with asymmetry datasets, as shown in table 1). Asymmetry items show loadings around $0.60(0.67,0.57,0.66$, and 0.61$)$. However, although they are below the usual cut-off of 0.70 , these items are not eliminated for two reasons. This is done, first, because of the theories supporting them that help to ensure the integrity of the construct, and second, because further analyses show that other reliability measures satisfy the acceptable criteria. These measures include Cronbach's alpha (all above 0.70 ) and composite reliability (all above 0.70). The AVEs are calculated and presented in tables 2, 3 and 4 for combined dataset, dyadic dataset and dyadic with asymmetry dataset, respectively. For all constructs (except for the asymmetry construct) the AVE exceeds the required level of 0.50. Applying the Fornell and Larcker (1981) tests for discriminant validity of the measures, it is confirmed that for all the constructs the AVE exceeds the squared correlation between the constructs. The AVE values for the asymmetry construct are below the typical cut-offs, however, asymmetry is not a conventional scale (see table 4). The closest gap between the AVE and the squared correlation can be identified in the case of the marketing-purchasing collaboration and the corresponding asymmetry measure of the marketing-purchasing collaboration $(\mathrm{AVE}=0.40$; squared correlation $=0.39)$. While these constructs are obviously related, they are conceptually very distinct and overall discriminant validity is confirmed.

--- Insert Tables 2, 3 and 4 about Here---

All path coefficients are significant and as hypothesized. Overall, the fit indices are good. The results of the analysis of Model 1a, i.e. the combined dataset (figure 2a), indicate a good fit: Chi square $/ \mathrm{df}=1.119(\mathrm{p}=0.227), \mathrm{RMR}=0.047, \mathrm{GFI}=0.929, \mathrm{CFI}=0.992, \mathrm{RMSEA}=0.028$ 
$(\mathrm{p}=0.877)$. The model explains $19.1 \%$ of the variance of customer orientation, $20.8 \%$ of marketing-purchasing collaboration, and 5.7\% of business performance. As it can be expected that a multitude of aspects drive business performance, the explained variance of the main focal construct, i.e. marketing-purchasing collaboration, represents the relevant benchmark for comparison with the other models.

Before testing dyadic operationalizations, two additional models (Model 1b and Model 1c) are tested in order to provide comparisons and examine the robustness of the analysis. Model $1 \mathrm{~b}$ is based on the marketing dataset, using a fully monadic operationalization with data only from the marketing side $(\mathrm{CFA}$ : Chi square $/ \mathrm{df}=1.431(\mathrm{p}=0.010), \mathrm{RMR}=0.065, \mathrm{GFI}=0.911, \mathrm{CFI}=$ $0.975, \operatorname{RMSEA}=0.054(\mathrm{p}=0.369))$. The model indicates an acceptable fit: Chi square $/ \mathrm{df}=1.579$ $(\mathrm{p}=0.001), \mathrm{RMR}=0.081, \mathrm{GFI}=0.901, \mathrm{CFI}=0.965, \mathrm{RMSEA}=0.063(\mathrm{p}=0.164)$, and explains $16.2 \%$ of the variance of customer orientation, $40.1 \%$ of marketing-purchasing collaboration, and $5.1 \%$ of business performance. The monadic purchasing model, uses a fully monadic operationalization with data only from the purchasing side and is called Model 1c (CFA: Chi square $/ \mathrm{df}=1.471(\mathrm{p}=0.011), \mathrm{RMR}=0.046, \mathrm{GFI}=0.924, \mathrm{CFI}=0.973, \mathrm{RMSEA}=0.057$ $\left.(\mathrm{p}=0.318)^{1}\right)$. Model $1 \mathrm{c}$ also indicates a good fit: Chi square $/ \mathrm{df}=1.584(\mathrm{p}=0.002), \mathrm{RMR}=0.053$, GFI $=0.914$, CFI $=0.965$, RMSEA $=0.063(\mathrm{p}=0.179)$. The model explains $19.2 \%$ of the variance of customer orientation, $29.1 \%$ of marketing-purchasing collaboration, und $5.6 \%$ of business performance. These monadic models provide a comparative basis before applying dyadic operationalization.

--- Insert Figure 2 about Here ---

\footnotetext{
${ }^{1}$ In the monadic purchasing dataset CFA adjustment required deleting item "Our business objectives are driven by customer satisfaction".
} 
Model 2 (see figure 3), using a dyadic dataset with a value operationalization, also provides a good fit, however, some of the fit indices are not as strong as the combined data model: Chi square $/ \mathrm{df}=1.328(\mathrm{p}=0.032), \mathrm{RMR}=0.048, \mathrm{GFI}=0.922, \mathrm{CFI}=0.983, \mathrm{RMSEA}=0.047$ $(\mathrm{p}=0.553)$.

\section{--- Insert Figure 3 about Here ---}

Overall, the dyadic model can be compared to different monadic models in two ways. First, a path-by-path analysis of the models can be applied in order to identify the paths which differ statistically between the models; and second, the explained variance of the model constructs is being compared. Overall, all models show similar results in a path-by-path comparison, however, one path differs statistically between the models: the customer orientation - marketingpurchasing collaboration path (H3). The difference is visible among the monadic models, i.e. Models 1a, 1b and 1c, and the dyadic model (Model 2). The path is stronger in Model $1 \mathrm{~b}$ (marketing dataset) and Model 2 (dyadic dataset). This difference can be explained theoretically through the different characteristics of the marketing and purchasing functions, i.e. marketing is more, purchasing usually less customer oriented (Sheth et al. 2009). Furthermore, there is a substantial increase in the variance explained in the dyadic model: Model 2 explains $26 \%$ of customer orientation, $43.5 \%$ of marketing-purchasing collaboration, and $11.3 \%$ of business performance. Therefore, the model comparisons demonstrate that a combined dataset model (Model 1a) is somewhat more accurate than purely monadic models (Models $1 \mathrm{~b}$ and 1c), while a dyadic model (Model 2) improves the explaining power of the model for all of the constructs.

Finally, our third analysis was based on the dyadic dataset including asymmetry measure of marketing-purchasing collaboration (Model 3; see figure 4). The goodness of fit indices are: Chi square $/ \mathrm{df}=1.458(\mathrm{p}=0.001), \mathrm{RMR}=0.046, \mathrm{GFI}=0.887, \mathrm{CFI}=0.963, \mathrm{RMSEA}=0.056$ 
$(\mathrm{p}=0.281)$. The strongest impact has been on the GFI index, while all the other indices showing acceptable goodness indices. The effect of adding the asymmetry construct has increased the model complexity, with a slight increase in explanatory power of customer orientation (26.5\%) in comparison with the dyadic dataset without the asymmetry measures, and a strong increase in comparison with the combined dataset model. The model explains business performance $(10.8 \%)$ better than in case of the combined dataset, but slightly worse than in case of the dyadic dataset without the asymmetry measures. However, the strongest effect is noticed when explaining the dyadic value operationalization of the marketing-purchasing collaboration (58.6\%), representing a considerable increase in the model's explanatory power compared to the combined dataset and the dyadic dataset without asymmetry measures.

\section{--- Insert Figure 4 about Here ---}

While the dyadic measurement increases the overall explanatory power of the model, adding asymmetry measures provides an opportunity to gain a deeper insight into the mechanism of the intra-construct relationships. Adding the asymmetry measure of marketing-purchasing collaboration has supported the suggested hypothesis of asymmetry and revealed the negative links between the constructs. Therefore, the dyadic value measure of marketing-purchasing interaction has a negative effect on the marketing-purchasing collaboration dyadic asymmetry measure $(-0.401(\mathrm{p}=0.000))$, identifying that the higher the intensity of the interaction, the lower the asymmetry measure of marketing-purchasing collaboration. In addition, there exists a negative link between the dyadic asymmetry and the dyadic value measure of marketingpurchasing collaboration $(-0.441(\mathrm{p}=0.000))$. Further tests revealed no significant direct effect of the collaboration asymmetry on business performance. 


\section{Discussion and conclusion}

\subsection{Discussion}

Our analysis has illustrated and compared the results of testing a conceptual model of marketing-purchasing collaboration, including two different dyadic constructs. We have tested the model based on pure monadic, combined, and dyadic datasets (value operationalization as well as asymmetry measures). Each approach has revealed certain strengths: the results of the combined dataset model test have shown the best goodness of fit index measures and provided support for the tested hypotheses. However, the explanatory power of monadic models is the lowest among the different tests. Dyadic datasets have dramatically increased the explanatory power of the model, resulting in a particularly high share of variance explained for the marketing-purchasing collaboration as the core construct of the model. The very nature of this construct would advocate dyadic data collection and analysis as an appropriate operationalization, as it directly involves the dyad of marketing and purchasing departments in its conceptualization. However, using dyadic data, despite increasing the explanatory power, has not provided very strong goodness of fit indices. The combination of dyadic measures (value and asymmetry operationalization) for the same construct leads to an even stronger explanatory power. However, again the goodness of fit of the model is somewhat weaker.

\subsection{Theoretical and managerial implications}

Applying a dyadic approach in business relationships has been repeatedly recommended in the literature (Benson 1975; Anderson et al. 1994; Svensson 2004). However, there exists a lack of guidance concerning the introduction, comparison and contrasting of the relevant operationalization techniques that can be employed. Our paper provides an overview of various potential dyadic operationalizations. We introduced different techniques to aggregate dyadic 
data, capturing its richness and variations. Exemplifying a model of marketing-purchasing collaboration and testing it based on an existing empirical dataset, we examined two subconstructs (i.e. dyadic value and asymmetry). Hypotheses were developed and tested based on both dyadic value and asymmetry. The results supported the suggested hypotheses. This validates the role of asymmetry operationalization in particular, which provides additional insights via aggregating dyadic data. Focusing on dyadic differences is in line with previous research, advocating alignment and matching strategies (Workman et al. 1998; Swaminathan et al. 2008; Esper et al. 2010), which argues that the alignment of organizational views and organizational processes enhances cross-functional collaboration (Workman et al. 1998), particularly between demand-focused processes and supply-focused processes (Esper et al. 2010). In the current study such internal alignment is examined in the context of the marketingpurchasing collaboration (internal) dyad. By doing so, we extend the limited literature in business marketing in an attempt to make better sense of quantitative dyadic data. Using alternative model comparisons, we contrasted three different ways of operationalizing dyadic data (combined, dyadic, and dyadic with asymmetry). The results indicate the strengths and weaknesses of each technique. The significance of dyadic symmetry reminds practitioners about the relevance and importance of win-win and inclusive relationships. It shows that managers should note that all involved parties should benefit from the relationship and perceive it as both positive and collaborative (as opposed to asymmetric, one-sided, and being based on opportunistic attitudes towards the relationship) to ensure an effective liaison.

Businesses are recommended to achieve higher degrees of customer orientation and marketing-purchasing interaction to improve collaboration between marketing and purchasing departments and consequently their performance. Marketing-purchasing collaboration on 
business performance is effective in two forms. First, businesses should incentivize an increase of the inter-functional collaboration between the marketing and the purchasing department, as such collaboration drives important business outcomes. Secondly, they should develop an alignment between the collaboration perceptions of the involved departments, as symmetry between them, i.e. congruence, positively influences collaboration itself. This alignment can be enhanced by higher levels of marketing-purchasing interaction. The misalignment between departments' perceptions regarding the inter-functional collaboration dampens the combinatory value of the two departments' collaboration. Therefore, perception matching in a dyadic relationship regarding the understanding of the two entities' collaboration plays a role in enhancing the overall firm performance.

\subsection{Conclusion and limitations}

We have summarized three different operationalizations in the context of business relationships with an emphasis on the data characteristics: monadic, perceived dyadic, and dyadic. We discussed three aggregation techniques with the purpose of making better sense of quantitative dyadic data: value, asymmetry, and directional asymmetry. Certain dyadic operationalizations can operate on the level of the business relationship as the unit of analysis, with the units of observation being the different involved parties. Using quantitative dyadic data and selecting the appropriate approach to operationalize constructs and aggregate data assist the researcher in gaining a more fine-grained understanding of the phenomenon under investigation. Dyadic datasets provide the opportunity to better understand business marketing relationships and intra-organizational relational phenomena (Anderson and Weitz 1992; Anderson et al. 1994; Deshpandé et al. 2000). In this study, we reviewed different ways of collecting quantitative data from monadic towards rigorous dyadic. Different methods vary in terms of difficulty and the 
type of access needed. However, it is necessary to develop aggregation techniques that incorporate the richness of this data (Johnston and Bonoma 1981; Palmatier et al. 2007). This includes dyadic-level aggregation (e.g. value, asymmetry sub-sets) as well as pertinent propositions (e.g. sub-construct hypotheses), which contribute to the appropriate use of the data and lead to valuable knowledge about the concepts under investigation (e.g. business marketing and relationship constructs).

Based on the theoretical discussions, and an empirical exemplification using internal matchpaired dyadic data, we argue that quantitative research can be conducted from a dyadic perspective. Furthermore, business relationships can (and arguably should) be operationalized at a dyadic level. Therefore, characteristics of the relationship dyad can be measured and employed. However, our empirical example shows that such dyadic operationalizations, while contributing to an increase in explanatory power of the model, show decreased goodness-of-fit indices. Further research needs to ascertain whether this trade-off between explanatory value and model fit represents a general characteristic of using dyadic data. With our analyses we make a methodological contribution with a focus on dyadic quantitative methods. Future studies need to explore the dyadic operationalization of constructs using alternative techniques. For instance polynomial regression could provide additional understanding of dyadic constructs (see Shanock et al. 2010; Mullins et al. 2014). In our example, different levels of business operation are used. Future research should also investigate the use of multi-level dyadic data to investigate dyadic interactions, incorporating perspectives collected from different levels (i.e. multi-level positions such as a salesperson, a middle manager and a senior manager) of each party and pairing them.

Finally, the specifics of the Russian market correlates with those discussed in the literature peculiarities of other emerging economies (Burgess and Steenkamp 2006; Sheth 2011). 
However, in case of the Russian economy, these peculiarities are complemented by the features of a market in transition. Among the constructs used in the study, the construct of customer orientation is critical and idiosyncratic for Russian firms. Farley and Deshpandé (2006) have argued that customer orientation will represent the strongest change for Russian firms, shifting from a previously dominating "supplier orientation". Despite these earlier forecasts, existing research points to the lack of customer orientation (Roersen et al. 2013), although firms do claim to have invested in customer orientation. In the context of our study, this may have caused an overestimation of the customer orientation. This is a limitation that future studies should address by using methodologies such as comparative research. 


\section{References}

Alvarez, Leticia Suarez, Rodolfo Vazquez Casielles, and Ana Maria Diaz Martin. 2010. "Analysis of the Role of Complaint Management in the Context of Relationship Marketing." Journal of Marketing Management no. 27 (1-2):143-164.

Anderson, Erin, and Barton Weitz. 1992. "The Use of Pledges to Build and Sustain Commitment in Distribution Channels." Journal of Marketing Research no. 29 (1):18-34.

Anderson, James C., and David W. Gerbing. 1988. "Some Methods for Respecifying Measurement Models to Obtain Unidimensional Construct Measurement." Journal of Marketing Research no. 19 (4):453-460.

Anderson, James C., Håkan Håkansson, and Jan Johanson. 1994. "Dyadic Business Relationships within a Business Network Context." Journal of Marketing no. 58 (4):1-15.

Anderson, James C., and James A. Narus. 1990. "A Model of Distributor Firm and Manufacturer Firm Working Partnerships." Journal of Marketing no. 54 (1): 42-58.

Auh, Seigyoung, and Chuan-Fong Shih. 2005. "The Relative Effects of Relationship Quality and Exchange Satisfaction on Customer Loyalty." Journal of Business-to-Business Marketing no. 12 (2):73-100.

Barnes, Bradley R., Pete Naudé, and Paul Michell. 2005. "Exploring Commitment and Dependency in Dyadic Relationships." Journal of Business-to-Business Marketing no. 12 (3):1-26.

Benson, J. Kenneth. 1975. "The Interorganizational Network as a Political Economy." Administrative Science Quarterly no. 20 (2):229-249.

Blesa, Andreu, and Enrique Bigné. 2005. "The Effect of Market Orientation on Dependence and Satisfaction in Dyadic Relationships." Marketing Intelligence and Planning no. 23 (2/3):249-265.

Boukis, Achilleas, and Spiros Gounaris. 2015. Some Preliminary Evidence for the Effect of Employee Satisfaction on Relational Switching Costs. Paper read at Sustainable Global Marketplace.

Brach, Simon, Gianfranco Walsh, Thorsten Hennig-Thurau, and Markus Groth. 2015. "A Dyadic Model of Customer Orientation: Mediation and Moderation Effects." British Journal of Management no. 26 (2):292-309.

Bstieler, Ludwig, Martin Hemmert, and Gloria Barczak. 2017. "The Changing Bases of Mutual Trust Formation in Inter-Organizational Relationships: A Dyadic Study of UniversityIndustry Research Collaborations." Journal of Business Research no. 74:47-54.

Bucklin, Louis P., and Sanjit Sengupta. 1993. "Organizing Successful Co-Marketing Alliances." Journal of Marketing no. 57 (2):32-46.

Buijzen, Moniek, and Patti M. Valkenburg. 2003. "The Unintended Effects of Television Advertising: A Parent-Child Survey." Communication Research.

Burgess, Steven Michael, and Jan-Benedict E. M. Steenkamp. 2006. "Marketing Renaissance: How Research in Emerging Markets Advances Marketing Science and Practice." International Journal of Research in Marketing no. 23 (4):337-356.

Cadogan, John W., Sanna Sundqvist, Risto T. Salminen, and Kaisu Puumalainen. 2005. "Export Marketing, Interfunctional Interactions, and Performance Consequences." Journal of the Academy of Marketing Science no. 33 (4):520-535.

Cao, Mei, and Qingyu Zhang. 2011. "Supply Chain Collaboration: Impact on Collaborative Advantage and Firm Performance." Journal of Operations Management no. 29 (3):163180.

Cavusgil, S. Tamer, Seyda Deligonul, and Chun Zhang. 2004. "Curbing Foreign Distributor Opportunism: An Examination of Trust, Contracts, and the Legal Environment in International Channel Relationships." Journal of International Marketing no. 12 (2):7-27. 
Day, George S. 1990. Market Driven Strategy. New York: The Free Press.

. 1994. "The Capabilities of Market-Driven Organizations." Journal of Marketing no. 58 (4):37-52.

De Ruyter, Ko, Luci Moorman, and Jos Lemmink. 2001. "Antecedents of Commitment and Trust in Customer-Supplier Relationships in High Technology Markets." Industrial Marketing Management no. 30 (3):271-286.

DelVecchio, Susan. 1996. "Differences in Salesperson and Manager Perceived Control: A Comparison of Dyadic Disagreements." Journal of Business and Industrial Marketing no. 11 (2):60-72.

Deshpandé, Rohit, John U. Farley, and Frederick E. Webster. 1993. "Corporate Culture, Customer Orientation, and Innovativeness in Japanese Firms - a Quadrad Analysis." Journal of Marketing no. 57 (1):23-27.

—. 2000. "Triad Lessons: Generalizing Results on High Performance Firms in Five Business-to-Business Markets." International Journal of Research in Marketing no. 17 (4):353-362.

Dess, Gregory G., Stephanie Newport, and Abdul M. A. Rasheed. 1993. "Configuration Research in Strategic Management: Key Issues and Suggestions." Journal of Management no. 19 (4):775-795.

Diamantopoulos, Adamantios, and Judy A. Siguaw. 2006. "Formative Versus Reflective Indicators in Organizational Measure Development: A Comparison and Empirical Illustration." British Journal of Management no. 17 (4):263-282.

Dwyer, F. Robert, Paul H. Schurr, and Sejo Oh. 1987. "Developing Buyer-Seller Relationships." Journal of Marketing no. 51 (2):11-27.

Dyer, Jeffrey H. 1996. "Specialized Supplier Networks as a Source of Competitive Advantage: Evidence from the Auto Industry." Strategic Management Journal no. 17 (4):271-291.

Dyer, Jeffrey H., and Harbir Singh. 1998. "The Relational View: Cooperative Strategy and Sources of Interorganizational Competitive Advantage." Academy of Management Review no. 23 (4):660-679.

Elo, Maria, Christiane Benjowsky, and Niina Nummela. 2015. "Intercultural Competences and Interaction Schemes - Four Forces Regulating Dyadic Encounters in International Business." Industrial Marketing Management no. 48:38-49.

Esper, Terry, Alexander Ellinger, Theodore Stank, Daniel Flint, and Mark Moon. 2010. "Demand and Supply Integration: A Conceptual Framework of Value Creation through Knowledge Management." Journal of the Academy of Marketing Science no. 38 (1):5-18.

Farley, John U, and Rohit Deshpandé. 2006. "Charting the Evolution of Russian Firms from Soviet "Producer Orientation" to Contemporary "Market Orientation"." Journal of Global Marketing no. 19 (2):7-26.

Foley, Anthony, and John Fahy. 2004. "Towards a Further Understanding of the Development of Market Orientation in the Firm: A Conceptual Framework Based on the Market-Sensing Capability." Journal of Strategic Marketing no. 12 (4):219-230.

Ford, David, Lars-Erik Gadde, Håkan Håkansson, Ivan Snehota, and Alexandra Waluszewski. 2011. "Analysing Business Interaction." The IMP Journal no. 4 (1):82-103.

Fornell, Claes, and David F. Larcker. 1981. "Evaluating Structural Equation Models with Unobservable Variables and Measurement Error." Journal of Marketing Research no. 18 (1):39-50.

Gadde, Lars-Erik. 2004. "Activity Coordination and Resource Combining in Distribution Networks - Implications for Relationship Involvement and the Relationship Atmosphere." Journal of Marketing Management no. 20 (1/2):157-184.

Gilliland, David I., and Daniel C. Bello. 2002. "Two Sides to Attitudinal Commitment: The Effect of Calculative and Loyalty Commitment on Enforcement Mechanisms in Distribution Channels." Journal of the Academy of Marketing Science no. 30 (1):24-43. 
Gummesson, Evert. 2010. "Business in Networks, by Håkan Håkansson, David Ford, Lars-Erik Gadde, Ivan Snehota and Alexandra Waluszewski -- Wiley, Uk, 2009, 308 Pp." Journal of Business-to-Business Marketing no. 17 (3):308-316.

Håkansson, Håkan, and Ivan Snehota. 1989. "No Business Is an Island: The Network Concept of Business Strategy." Scandinavian Journal of Management no. 5 (3):187-200.

Heide, Jan B. 1994. "Interorganisational Governance in Marketing Channels." Journal of Marketing no. 58 (1):71-85.

Holmlund-Rytkönen, Maria, and Tore Strandvik. 2005. "Stress in Business Relationships." Journal of Business \& Industrial Marketing no. 20 (1):12-22.

Homburg, Christian, and Ove Jensen. 2007. "The Thought Worlds of Marketing and Sales: Which Differences Make a Difference?" Journal of Marketing no. 71 (3):124-142.

Jap, Sandy D., and Shankar Ganesan. 2000. "Control Mechanisms and the Relationship Life Cycle: Implications for Safeguarding Specific Investments and Developing Commitment." Journal of Marketing Research no. 37 (2):227-245.

Jaworski, Bernard J, and Ajay K. Kohli. 1993. "Market Orientation: Antecedents and Consequences." Journal of Marketing no. 57 (3):53-70.

Johnston, Wesley J., and Thomas V. Bonoma. 1981. "The Buying Center: Structure and Interaction Patterns." Journal of Marketing no. 45 (3):143-156.

Johnston, Wesley J., and J. E. Lewin. 1996. "Organizational Buying Behavior: Toward an Integrative Framework." Journal of Business Research no. 35 (1):1-15.

Jöreskog, Karl G., and Dag Sörbom. 1988. Lisrel7: A Guide to the Program and Applications. Chicago, IL: SPSS Inc.

Joshi, Ashwin W. 2009. "Continous Suplier Performance Improvement: Effects of Collaborative Communication and Control." Journal of marketing no. 73 (1):133-150.

Jüttner, Uta, Martin Christopher, and Susan Baker. 2007. "Demand Chain Management Integrating Marketing and Supply Chain Management." Industrial Marketing Management no. 36 (3):377-392.

Kahn, Kenneth B., and John T. Mentzer. 1996. "Logistics and Interdepartmental Integration." International Journal of Physical Distribution and Logistics Management no. 26 (8):6-14. 1998. "Marketing's Integration with Other Departments." Journal of Business Research no. 42 (1):53-62.

Klein, Katherine J., Fred Dansereau, and Rosalie J. Hall. 1994. "Levels Issues in Theory Development, Data Collection, and Analysis." Academy of Management Review no. 19 (2):195-229.

Klein, Richard, Arun Rai, and Detmar W. Straub. 2007. "Competitive and Cooperative Positioning in Supply Chain Logistics Relationships." Decision Sciences no. 38 (4):611646.

Kline, Rex B. 2005. Principles and Practice of Structural Equation Modeling. 2nd ed. New York: Guildford Press.

Kohli, Ajay K., and Bernard J. Jaworski. 1990. "Market Orientation: The Construct, Research Propositions, and Managerial Implications." Journal of Marketing no. 54 (2):1-18.

Kumar, Alok, Jan B. Heide, and Kenneth H. Wathne. 2011. "Performance Implications of Mismatched Governance Regimes across External and Internal Relationships." Journal of Marketing no. 75 (2):1-17.

Kumar, Nirmalya, Lisa K. Scheer, and Jan-Benedict E. M. Steenkamp. 1995a. "The Effects of Perceived Interdependence on Dealer Attitudes." Journal of Marketing Research no. 32 (3):348-356.

Kumar, Nirmalya, LK Scheer, and JE Steenkamp. 1995b. "The Effects of Supplier Fairness on Vulnerable Resellers." Journal of Marketing Research no. 32 (1): 5-65. 
Le Meunier-FitzHugh, Ken, and Nigel F. Piercy. 2007. "Does Collaboration between Sales and Marketing Affect Business Performance?" Journal of Personal Selling \& Sales Management no. 27 (3):207-220.

Liu, Hefu, Weiling Ke, Kwok Kee Wei, and Zhongsheng Hua. 2013. "Effects of Supply Chain Integration and Market Orientation on Firm Performance." International Journal of Operations \& Production Management no. 33 (3):322-346.

Macht, Stephanie A. 2011. "The Role of Investee Company Managers in Business Angels' Involvement: Empirical Insights from Dyadic Data." Venture Capital no. 13 (3):267-293.

MacKenzie, Scott B., Philip M. Podsakoff, and Cheryl Burke Jarvis. 2005. "The Problem of Measurement Model Misspecification in Behavioral and Organizational Research and Some Recommended Solutions." Journal of Applied Psychology no. 90 (4):710-730.

Maltz, Elliot, and Ajay K. Kohli. 1996. "Market Intelligence Dissemination across Functional Boundaries." Journal of Marketing Research no. 33 (1):47-61.

Mohr, Jakki J., Robert J. Fisher, and John R. Nevin. 1996. "Collaborative Communication in Interfirm Relationships: Moderating Effects of Integration and Control." Journal of Marketing no. 60 (3):103-115.

Mohr, Jakki, and John R. Nevin. 1990. "Communication Strategies in Marketing Channels: A Theoretical Perspective." Journal of Marketing no. 54 (4):36-51.

Morgan, Robert M., and Shelby D. Hunt. 1994. "The Commitment-Trust Theory of Relationship Marketing." Journal of Marketing no. 58 (3):20-39.

Mullins, Ryan R., Michael Ahearne, Son K. Lam, Zachary R. Hall, and Jeffrey P. Boichuk. 2014. "Know Your Customer: How Salesperson Perceptions of Customer Relationship Quality Form and Influence Account Profitability." Journal of Marketing no. 78 (6):38-58.

Narver, John C., and Stanley F. Slater. 1990. "The Effect of a Market Orientation on Business Profitability." Journal of Marketing no. 54 (4):20-35.

Nonaka, Ikujiro. 1994. "A Dynamic Theory of Organizational Knowledge Creation." Organization Science no. 5 (1):14-37.

Nonaka, Ikujiro, Katsuhiro Umemoto, and Dai Senoo. 1996. "From Information Processing to Knowledge Creation: A Paradigm Shift in Business Management." Technology in Society no. 18 (2):203-218.

Palmatier, Robert W., Lisa K. Scheer, and Jan-Benedict E.M. Steenkamp. 2007. "Customer Loyalty to Whom? Managing the Benefits and Risks of Salesperson-Owned Loyalty." Journal of Marketing Research no. 44 (2):185-199.

Podsakoff, Philip M., Scott B. MacKenzie, Jeong-Yeon Lee, and Nathan P. Podsakoff. 2003. "Common Method Biases in Behavioral Research: A Critical Review of the Literature and Recommended Remedies." Journal of Applied Psychology no. 88 (5):879-903.

Reid, David A., and Richard E. Plank. 2000. "Business Marketing Comes of Age: A Comprehensive Review of the Literature." Journal of Business-to-Business Marketing no. $7(2 / 3): 9-186$.

Rodriguez, Carlos M., and David T. Wilson. 2002. "Relationship Bonding and Trust as a Foundation for Commitment in U.S. Mexican Strategic Alliances: A Structural Equation Modeling Approach." Journal of International Marketing no. 10 (4):53-76.

Roersen, Mariska J., Jeroen Kraaijenbrink, and Aard J. Groen. 2013. "Marketing Ignorance and the Validity of Narver and Slater's Mktor Scale in High-Tech Russian Firms." Journal of Product Innovation Management no. 30 (3):545-559.

Rousseau, Denise M. 1985. "Issue of Level in Organizational Research: Multi-Level and Cross Level Perspectives." In Research in Organizational Behavior, edited by L. Cummings and B. Staw, 1-37. Greenwich, CT: JAI Press.

Ruekert, Robert W., and Orville C. Walker. 1987. "Marketing's Interaction with Other Functional Units: A Conceptual Framework and Empirical Evidence." Journal of Marketing no. 51 (1):1-19. 
Salmi, Asta. 2004. Institutional Change of Business Networks: Russian Transition Revisited. Paper read at Proceedings, 20th IMP conference, Copenhagen, Denmark.

Shanock, Linda Rhoades, Benjamin E Baran, William A Gentry, Stacy Clever Pattison, and Eric D Heggestad. 2010. "Polynomial Regression with Response Surface Analysis: A Powerful Approach for Examining Moderation and Overcoming Limitations of Difference Scores." Journal of Business and Psychology no. 25 (4):543-554.

Sheth, Jagdish N, Arun Sharma, and Gopalkrishnan R lyer. 2009. "Why Integrating Purchasing with Marketing Is Both Inevitable and Beneficial." Industrial Marketing Management no. 38 (8):865-871.

Sheth, Jagdish N. 2011. "Impact of Emerging Markets on Marketing: Rethinking Existing Perspectives and Practices." Journal of Marketing no. 75 (4):166-182.

Simangunsong, Elliot. 2013. "Analysing Parallel Interaction in Supply Chains: A Supply Chain Network Perspective." International Research Journal of Business Studies no. 6 (3):171184.

Slater, Stanley F., and John C. Narver. 1994. "Does Competitive Environment Moderate the Market Orientation-Performance Relationship?" Journal of Marketing no. 58 (1):46-55.

Smirnova, Maria, Stephan C. Henneberg, Bahar Ashnai, Peter Naudé, and Stefanos Mouzas. 2011. "Understanding the Role of Marketing-Purchasing Collaboration in Industrial Markets: The Case of Russia." Industrial Marketing Management no. 40 (1):54-64.

Straub, Detmar, Arun Rai, and Richard Klein. 2004. "Measuring Firm Performance at the Network Level: A Nomology of the Business Impact of Digital Supply Networks." Journal of Management Information Systems no. 21 (1):83-114.

Svensson, Göran. 2004. "Interactive Vulnerability in Buyer-Seller Relationships: A Dyadic Approach." International Journal of Physical Distribution and Logistics Management no. 34 (8):662-682.

Swaminathan, Vanitha, Feisal Murshed, and John Hulland. 2008. "Value Creation Following Merger and Acquisition Announcements: The Role of Strategic Emphasis Alignment." Journal of Marketing Research no. 45 (1):33-47.

Tjosvold, Dean, and Choy Wong. 1994. "Working with Customers: Cooperation and Competition in Relational Marketing." Journal of Marketing Management no. 10:297-310.

Tsai, Wenpin. 2001. "Knowledge Transfer in Intraorganizational Networks: Effects of Network Position and Absorptive Capacity on Business Unit Innovation and Performance." The Academy of Management Journal no. 44 (5):996-1004.

Van Bruggen, G. H., G. L. Lilien, and M. Kacker. 2002. "Informants in Organizational Marketing Research: Why Use Multiple Informants and How to Aggregate Responses." Journal of Marketing Research no. 39 (4):469-478.

Vorhies, Douglas W., and Michael Harker. 2000. "The Capabilities and Performance Advantages of Market-Driven Firms: An Empirical Investigation." Australian Journal of Management no. 25 (2):145-171.

Whipple, Judith M., Robert Wiedmer, and Kenneth K. Boyer. 2015. "A Dyadic Investigation of Collaborative Competence, Social Capital, and Performance in Buyer-Supplier Relationships." Journal of Supply Chain Management no. 51 (2).

Workman, John P, Jr, Christian Homburg, and Kjell Gruner. 1998. "Marketing Organization: An Integrative Framework of Dimensions and Determinants." Journal of Marketing no. 62 (July):21-41. 
Figure 1: Types of Quantitative Operationalizations of Business Relationships

\section{Monad}

Actor A

-

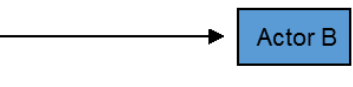

\section{Perceived Dyad}
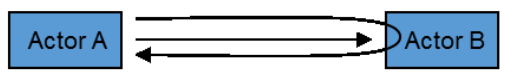

\section{Dyad}

Actor A: To what extent do you collaborate closely in your relationship with Actor B?

Actor A: To what extent do you collaborate closely in your relationship with Actor $B$ ?

Actor A: To what extent does Actor B collaborates closely in its relationship with you?

Actor A: To what extent do you collaborate closely in your relationship with Actor $B$ ? Actor B: To what extent do you collaborate closely in your relationshipwith Actor A? 
Figure 2: Path Estimation Original Model

Figure 2a: Path Estimation Original Model (combined dataset), Model 1a

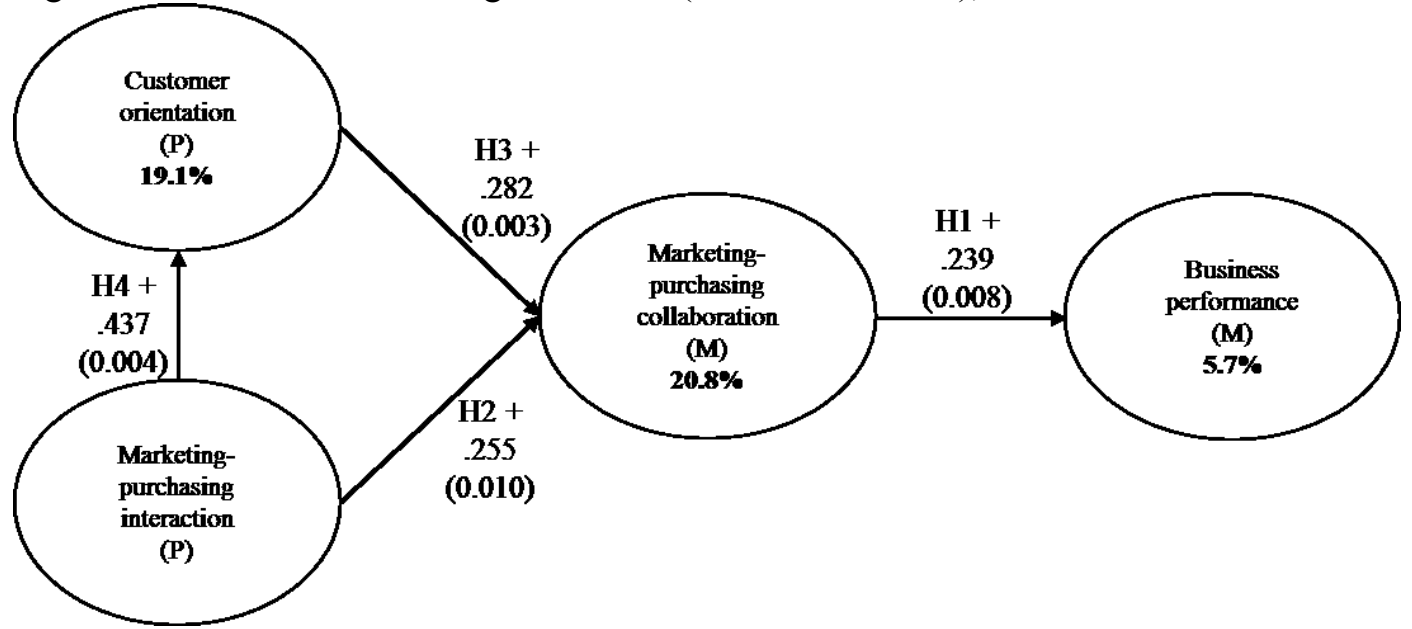

Note: $\mathrm{P}$ and $\mathrm{M}$ indicate construct being measured using the data collected from purchasing and marketing respondents respectively

Figure 2b: Path Estimation Original Model (marketing dataset), Model 1b

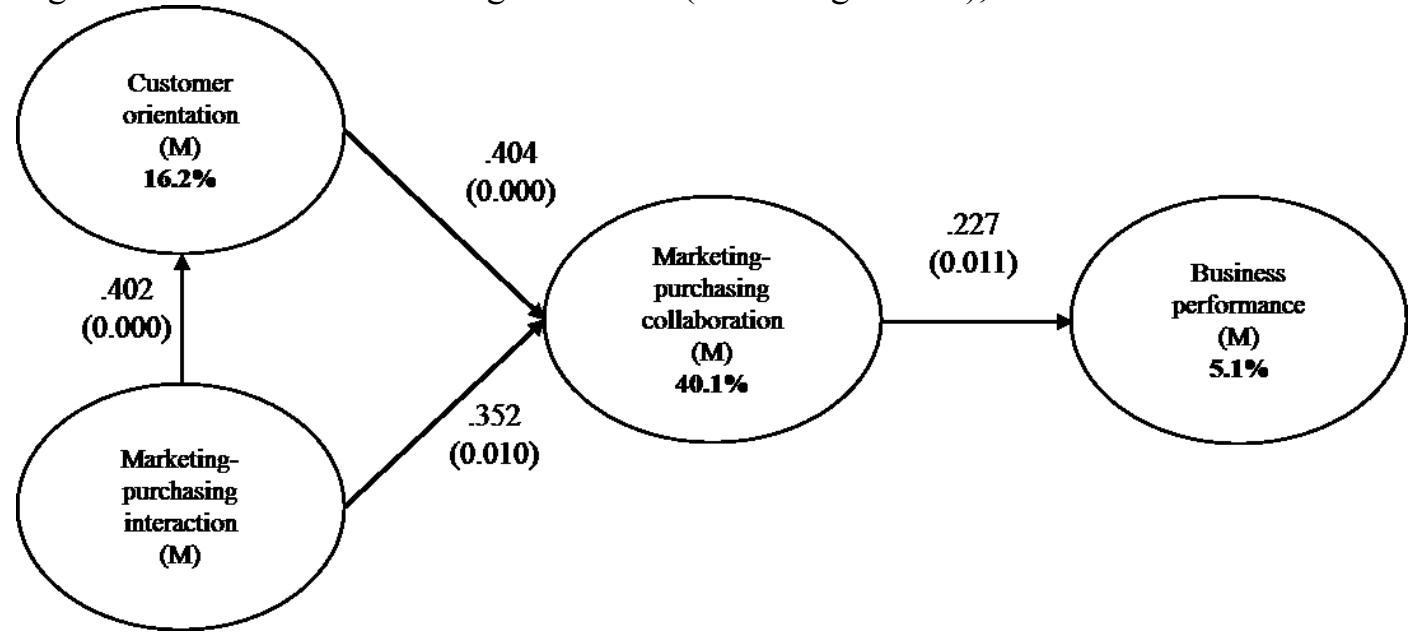

Figure 2c: Path Estimation Original Model (purchasing dataset), Model 1c

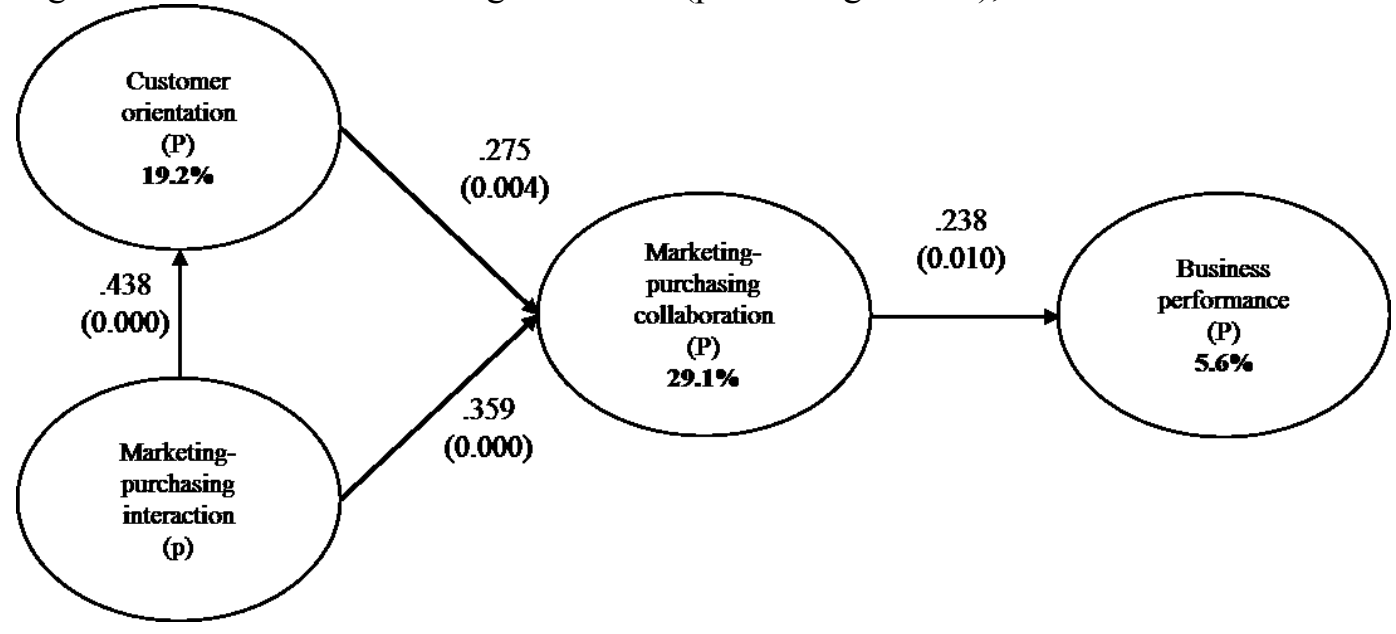


Figure 3: Path Estimation (dyadic values dataset), Model 2

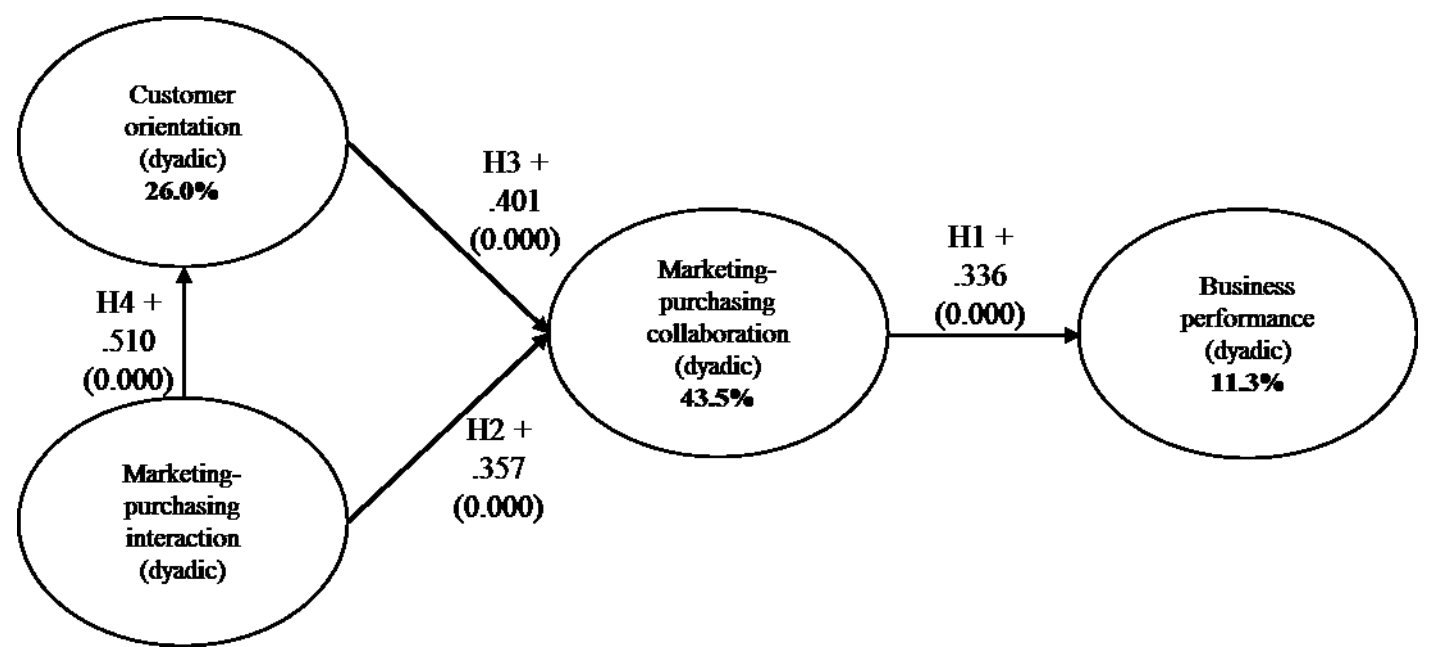

Note: (dyadic) indicates construct being measured as the average values of the scores from purchasing and marketing respondents 
Figure 4: Path Estimation (dyadic value and asymmetry dataset), Model 3

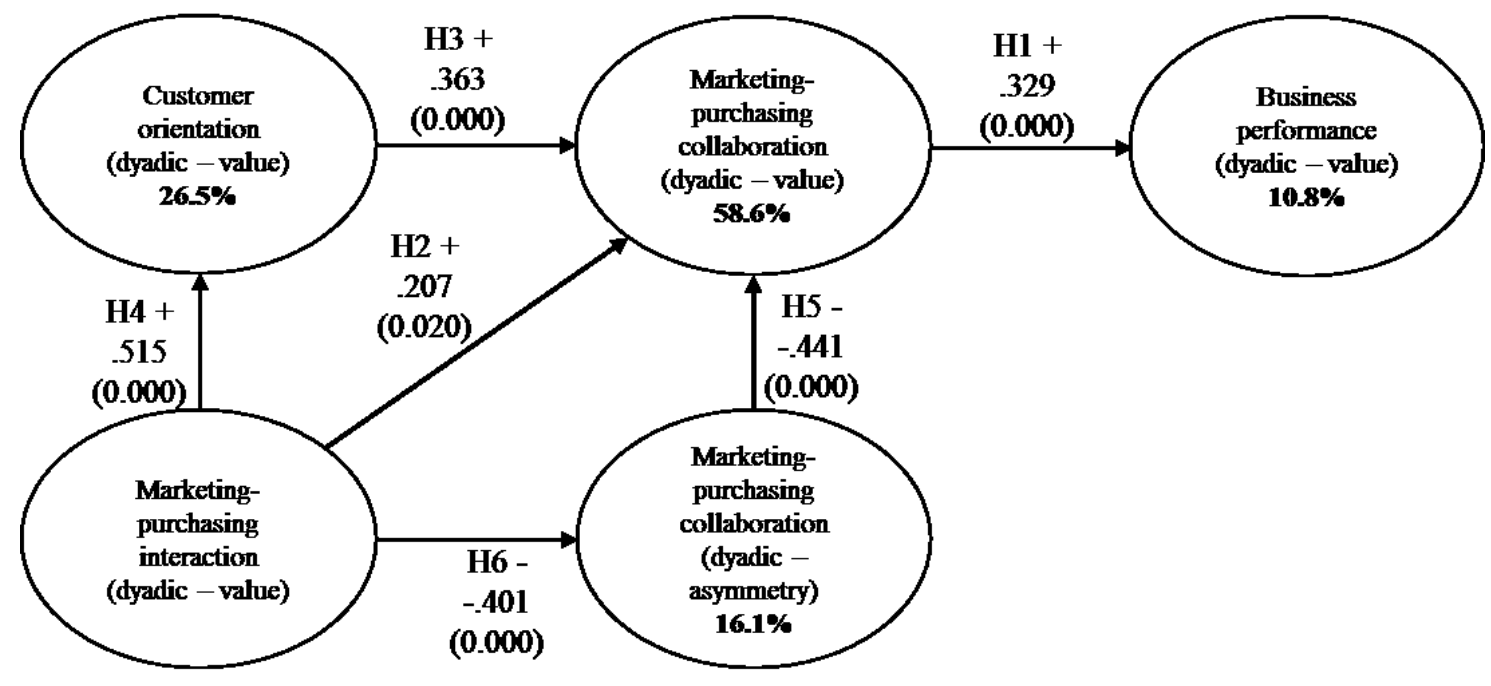


Table 1: Measurement Statistics (combined and dyadic datasets)

\begin{tabular}{|c|c|c|c|c|c|c|}
\hline Construct/items & $\begin{array}{l}\text { Stand. } \\
\text { factor } \\
\text { loading }\end{array}$ & $\begin{array}{l}\text { Cronbach's } \\
\text { Alpha }\end{array}$ & CR & $\begin{array}{l}\text { Stand. } \\
\text { factor } \\
\text { loading }\end{array}$ & $\begin{array}{l}\text { Cronbach's } \\
\text { Alpha }\end{array}$ & $\mathbf{C R}$ \\
\hline Customer orientation & \multicolumn{3}{|c|}{ (Purchasing) } & \multicolumn{3}{|c|}{ (Dyadic) } \\
\hline & & 0.90 & 0.89 & & 0.89 & 0.90 \\
\hline $\begin{array}{l}\text { We closely monitor and } \\
\text { assess our level of } \\
\text { commitment in serving } \\
\text { customer's needs. }\end{array}$ & 0.84 & & & 0.87 & & \\
\hline $\begin{array}{l}\text { Business strategies are } \\
\text { driven by the goal of } \\
\text { increasing customer value. }\end{array}$ & 0.90 & & & 0.89 & & \\
\hline $\begin{array}{l}\text { Our business objectives are } \\
\text { driven by customer } \\
\text { satisfaction. }\end{array}$ & 0.77 & & & 0.81 & & \\
\hline $\begin{array}{l}\text { Marketing-purchasing } \\
\text { interaction }\end{array}$ & \multicolumn{3}{|c|}{ (Purchasing) } & \multicolumn{3}{|c|}{ (Dyadic) } \\
\hline & & 0.82 & 0.84 & & 0.81 & 0.83 \\
\hline Meetings & 0.75 & & & 0.79 & & \\
\hline Committees/Task forces & 0.77 & & & 0.85 & & \\
\hline Phone conversations & 0.88 & & & 0.81 & & \\
\hline Emails & 0.60 & & & 0.51 & & \\
\hline $\begin{array}{l}\text { Marketing-purchasing } \\
\text { collaboration }\end{array}$ & \multicolumn{3}{|c|}{ (Marketing) } & \multicolumn{3}{|c|}{ (Dyadic) } \\
\hline & & 0.89 & 0.90 & & 0.92 & 0.93 \\
\hline Achieve goals collectively & 0.82 & & & 0.91 & & \\
\hline $\begin{array}{l}\text { Have a mutual } \\
\text { understanding }\end{array}$ & 0.89 & & & 0.91 & & \\
\hline $\begin{array}{l}\text { Share ideas, information } \\
\text { and/or resources }\end{array}$ & 0.77 & & & 0.79 & & \\
\hline Work together as a team & 0.86 & & & 0.88 & & \\
\hline Business performance & \multicolumn{3}{|c|}{ (Marketing) } & \multicolumn{3}{|c|}{ (Dyadic) } \\
\hline & & 0.88 & 0.88 & & 0.91 & 0.91 \\
\hline $\begin{array}{l}\text { Growth of comparative } \\
\text { market share }\end{array}$ & 0.91 & & & 0.90 & & \\
\hline Sales growth & 0.85 & & & 0.91 & & \\
\hline Business profitability & 0.76 & & & 0.81 & & \\
\hline Asymmetry & & & & \multicolumn{3}{|c|}{$\begin{array}{l}\text { (Dyadic: measured as marketing value } \\
\text { - purchasing value, absolute value) }\end{array}$} \\
\hline & & & & & 0.72 & 0.70 \\
\hline Achieve goals collectively & & & & 0.67 & & \\
\hline $\begin{array}{l}\text { Have a mutual } \\
\text { understanding }\end{array}$ & & & & 0.57 & & \\
\hline $\begin{array}{l}\text { Share ideas, information } \\
\text { and/or resources }\end{array}$ & & & & 0.66 & & \\
\hline Work together as a team & & & & 0.61 & & \\
\hline
\end{tabular}

Note : $\mathrm{CR}=$ composite reliability; all items are measured on a 5-point Likert scale, anchored in 'strongly agree' and 'strongly disagree' (except items for business performance which were anchored in 'much worse' and 'much better'). 
Table 2: Means, Standard Deviations, Correlations of the Constructs and AVE (combined dataset)

\begin{tabular}{lccccccr}
\hline Constructs & Mean & $\begin{array}{c}\text { Standard } \\
\text { deviation }\end{array}$ & $\mathbf{1}$ & $\mathbf{2}$ & $\mathbf{3}$ & $\mathbf{4}$ \\
\hline $\begin{array}{l}\text { 1. Customer orientation } \\
\begin{array}{l}\text { 2. Marketing-purchasing } \\
\text { interaction }\end{array}\end{array}$ & 4.55 & 0.59 & $\mathbf{0 . 6 6}$ & 0.18 & 0.16 & 0.05 \\
$\begin{array}{l}\text { 3. Marketing-purchasing } \\
\text { collaboration }\end{array}$ & 3.73 & 1.16 & $0.425^{* *}$ & $\mathbf{0 . 5 7}$ & 0.15 & 0.00 \\
$\begin{array}{l}\text { 4. Business performance } \\
\text { M }\end{array}$ & 0.67 & 0.89 & $0.399^{* *}$ & $0.382^{* *}$ & $\mathbf{0 . 6 9}$ & 0.05 \\
\hline
\end{tabular}

$* * \bar{p}<0.01$

Note: All constructs are scored on a scale of 1 to 5 , except for business performance which is scored on a scale of -2 to +2 . Below the diagonal - correlations between the constructs, above the diagonal - squared correlations, diagonal - AVEs. 
Table 3: Means, Standard Deviations and Correlations of the Constructs (dyadic dataset)

\begin{tabular}{lcccccc}
\hline Constructs & Mean & $\begin{array}{c}\text { Standard } \\
\text { deviation }\end{array}$ & $\mathbf{1}$ & $\mathbf{2}$ & $\mathbf{3}$ & $\mathbf{4}$ \\
\hline $\begin{array}{l}\text { 1. Customer orientation } \\
\begin{array}{l}\text { 2. Marketing-purchasing } \\
\text { interaction }\end{array}\end{array}$ & 4.51 & 0.57 & $\mathbf{0 . 7 4}$ & 0.25 & 0.34 & 0.16 \\
$\begin{array}{l}\text { 3. Marketing-purchasing } \\
\text { collaboration }\end{array}$ & 3.58 & 0.99 & $0.503^{* *}$ & $\mathbf{0 . 5 7}$ & 0.32 & 0.04 \\
$\begin{array}{l}\text { 4. Business performance } \\
\text { *** } \mathrm{p}<0.001, * * \mathrm{p}<0.01\end{array}$ & 0.72 & 0.69 & $0.398^{* *}$ & $0.196^{* *}$ & $0.321^{* *}$ & $\mathbf{0 . 7 7}$ \\
\hline
\end{tabular}

$* * * \mathrm{p}<0.001, * * \mathrm{p}<0.01$

Note: all constructs are scored on a scale of 1 to 5 , except for business performance which is scored on a scale of -2 to +2 . Below the diagonal (bold) - correlations between the constructs, above the diagonal - squared correlations, diagonal - AVEs. 
Table 4: Means, Standard Deviations and Correlations of the Constructs (dyadic dataset with asymmetry measure as absolute value)

\begin{tabular}{lcccccccc}
\hline Constructs & Mean & $\begin{array}{c}\text { Standard } \\
\text { deviation }\end{array}$ & $\mathbf{1}$ & $\mathbf{2}$ & $\mathbf{3}$ & $\mathbf{4}$ & $\mathbf{5}$ \\
\hline $\begin{array}{l}\text { 1. Customer orientation } \\
\begin{array}{l}\text { 2. Marketing-purchasing } \\
\text { interaction }\end{array}\end{array}$ & 4.51 & 0.57 & $\mathbf{0 . 7 4}$ & 0.26 & 0.33 & 0.17 & 0.08 \\
& 3.58 & 0.99 & $0.510^{* *}$ & $\mathbf{0 . 5 7}$ & 0.31 & 0.04 & 0.15 \\
$\begin{array}{l}\text { 3. Marketing-purchasing } \\
\text { collaboration }\end{array}$ & 4.11 & 0.77 & $0.579^{* *}$ & $0.561^{* *}$ & $\mathbf{0 . 7 6}$ & 0.11 & 0.39 \\
$\begin{array}{l}\text { 4. Business performance } \\
\begin{array}{l}\text { 5. Asymmetry measure } \\
\text { (absolute value) }\end{array}\end{array}$ & 0.72 & 0.69 & $0.412^{* *}$ & $0.197^{* *}$ & $0.326^{* *}$ & $\mathbf{0 . 7 7}$ & 0.00 \\
$* * * \mathrm{p}<0.001, * * \mathrm{p}<0.01$ & 0.59 & 0.55 & $-0.299^{* *}$ & $-0.393^{* * *}$ & $-0.626^{* * *}$ & -0.087 & $\mathbf{0 . 4 0}$ \\
\hline
\end{tabular}

Note: all constructs are scored on a scale of 1 to 5 , except for business performance which is scored on a scale of -2 to +2 . Below the diagonal (bold) - correlations between the constructs, above the diagonal - squared correlations, diagonal - AVEs. 


\section{Implications for Business Marketing Practice:}

\section{What is a Dyadic Understanding of Business Relationships?}

Business relationships are dyadic in nature, and hence a thorough understanding of business relationships should be based on a dyadic approach. This is in contrast to a monadic approach that examines the behavior or perceptions of just the focal party. The dyadic approach incorporates both sides of the relationship, exploring the perspectives and viewpoints of both parties involved. This implies that the only way to capture the qualities of a business relationship rigorously is via including the viewpoints of both parties involved, whether the marketing department and the purchasing department; the seller and the buyer; or the manufacturer and distributor. Capturing both parties' perspectives may take one of two approaches. The first is to base data collection on just the focal party itself, which implies asking one party for both their perceptions of the other, and also for their perceptions of what they think the other party thinks of them. So we could ask the marketing department about how they perceive the quality of the relationship with the purchasing department as well as how they think the purchasing department would evaluate that quality. This is termed the perceived dyadic approach. The alternative, the rigorous dyadic approach, involves collecting the data directly from both parties. This would involve asking both the marketing department and the purchasing department for their views on the quality of the relationship directly.

\section{How are Business Relationships Operationalized? And why Is It Important to}

\section{Operationalize Business Relationships?}

In today's data-driven world, business analytics can benefit immensely from data-driven strategies. Creating, maintaining and managing successful business relationships lead to business 
improvements. In order to manage the relationships, managers need to be aware about the statusquo of their existing relationships, compare and contrast them with each other, establish goals, monitor their improvements and evaluate the strategies and methods applied to manage them. Quantifiable measures of business relationship qualities are the building blocks to achieve such objectives. Business relationships are operationalized and measured by means of breaking down key aspects, using items and questions that capture those aspects and calculating certain features by aggregating those items (e.g. the level of collaboration is operationalized by measuring the level of business parties "working together as a team"; and "achieving goals collectively" and aggregating these items). Managers use these measures to evaluate the relationships and strategize their improvement.

\section{How Does the Dyadic Nature of Business Relationship Affect the Way It Should Be Managed?}

A one-sided evaluation of a business relationship can lead to misunderstanding; it lacks the rich and in-depth knowledge of relationship qualities. We therefore recommend managers and business parties to diligently pursue gaining insight about the perspectives of the business counterparts by interacting, communicating and interconnecting with them to achieve a true understanding about their viewpoints and perspectives in order to build a meaningful evaluation of the relationship. Whether the manager is managing an internal or an external business relationship, she or he should mind the perspectives and stakes of both (better to be said all) parties involved, build a comprehensive understanding of its state and manage it based on such careful comprehension. Particularly business practitioners should focus on how relationship qualities are perceived by both parties involved, noting three aspects: is the overall value 
(combination of two parties' evaluation) high or low? Do the two evaluations vary (is the difference high, or is there symmetry of the perceptions)? If there is a lack of symmetry, which party scores highly and which low and why? The answers to these questions are the building blocks towards a strong understanding of dyadic relationships and hint at remedies for improvement.

\section{What Is Perspectives' Symmetry and Alignment?}

As discussed above, a dyadic understanding of business relationships is based on including both parties' perspectives and viewpoints. Perspectives' symmetry is captured by measuring the similarity and overlap between the parties' perspectives regarding the qualities of a business relationship. If the parties have an overlapping and similar perspective, there is a perspectives' symmetry and alignment. This is as opposed situations in which the parties have different and varying perspectives, which leads to asymmetry. If there is asymmetry, the business practitioners should also be aware of the direction of the asymmetry. The directional asymmetry is measured not only by the difference and variance between the parties' perspectives, but also noting which party has a higher evaluation and which party has the lower.

\section{How Can Business People Benefit From Perspectives' Symmetry and Alignment?}

Our research showed that perspectives' symmetry and alignment regarding business relationship quality (i.e. collaboration) contributes to the quality itself. Therefore, in order to improve certain qualities of business relationships, business parties should work towards gaining a higher level of alignment via closing the gap between the parties' perspectives and achieving a symmetric dyadic evaluation. Alignment works towards improving the overall evaluation of the 
relationship quality and consequently improving the relationship outcomes and performance, explained in more detail in the following sections.

\section{How Can Managers Improve Marketing-Purchasing Collaboration and Relationship Performance?}

Managers should work towards improving customer orientation and marketing-purchasing interaction (interaction between the marketing department and the purchasing department) to achieve higher marketing-purchasing collaboration (collaboration between marketing and purchasing department). This will consequently enhance the relationship performance. Marketing-purchasing collaboration affects business performance and is effective in two ways. First, businesses should incentivize an increase of the inter-functional collaboration between the marketing and the purchasing departments, as such collaboration improves business outcomes and performance. Secondly, they should improve an alignment between the collaboration perceptions of the involved departments. This alignment and symmetry between perceptions positively influences collaboration itself. This alignment can be enhanced by improvement of marketing-purchasing interaction. Asymmetric and unbalanced viewpoints about the qualities of the relationship (in this case, collaboration) is a perceptual misalignment. Such misalignment (i.e. asymmetry) between departments' perceptions regarding the inter-functional collaboration affects the combinatory value of the two departments' collaboration. Therefore, perception matching in a dyadic relationship regarding the understanding of the two entities' collaboration plays a role in enhancing the overall firm performance. 
Appendix 1: A Classification of Quantitative Monadic and Dyadic Business Relationships

\begin{tabular}{|c|c|c|c|c|c|c|c|}
\hline $\begin{array}{l}\text { Monadic/ } \\
\text { perceived } \\
\text { dyadic/ } \\
\text { dyadic data } \\
\text { collection }\end{array}$ & Paper & Theory focus & Unit of analysis & $\begin{array}{l}\text { Measurement and } \\
\text { analysis }\end{array}$ & $\begin{array}{l}\text { Monadic/dyadic / } \\
\text { network } \\
\text { conceptualization }\end{array}$ & $\begin{array}{l}\text { Internal or } \\
\text { external } \\
\text { relationship }\end{array}$ & Dyadic operationalization \\
\hline $\begin{array}{l}\text { Monadic } \\
\text { data } \\
\text { collection }\end{array}$ & $\begin{array}{l}\text { (Anderson et } \\
\text { al. 1994) }\end{array}$ & $\begin{array}{l}\text { B2B relationships } \\
\text { within business } \\
\text { network }\end{array}$ & $\begin{array}{l}\text { Customer-supplier } \\
\text { relationship }\end{array}$ & $\begin{array}{l}\text { Validity assessment for } \\
\text { suggested measures }\end{array}$ & $\begin{array}{l}\text { Dyadic within } \\
\text { network }\end{array}$ & External & NA \\
\hline $\begin{array}{l}\text { Monadic } \\
\text { data } \\
\text { collection }\end{array}$ & $\begin{array}{l}\text { (Anderson } \\
\text { and Narus } \\
1990)\end{array}$ & $\begin{array}{l}\text { Distributor and } \\
\text { manufacturer } \\
\text { working } \\
\text { relationship }\end{array}$ & $\begin{array}{l}\text { Distributor- } \\
\text { manufacturer } \\
\text { relationship }\end{array}$ & $\begin{array}{l}\text { Separate model testing } \\
\text { and comparison (SEM) }\end{array}$ & Monadic & External & NA \\
\hline $\begin{array}{l}\text { Perceived } \\
\text { dyadic data } \\
\text { collection }\end{array}$ & $\begin{array}{l}\text { (Jap and } \\
\text { Ganesan } \\
\text { 2000) }\end{array}$ & $\begin{array}{l}\text { Control } \\
\text { mechanisms and } \\
\text { relationship life } \\
\text { cycle }\end{array}$ & $\begin{array}{l}\text { Retailer-supplier } \\
\text { relationship }\end{array}$ & SEM & Dyadic & External & $\begin{array}{l}\text { Dyadic magnitude is the } \\
\text { product of two scores and } \\
\text { dyadic asymmetry is their } \\
\text { difference }\end{array}$ \\
\hline $\begin{array}{l}\text { Perceived } \\
\text { dyadic data } \\
\text { collection }\end{array}$ & $\begin{array}{l}\text { (Kumar et al. } \\
\text { 1995b) }\end{array}$ & Interdependence & $\begin{array}{l}\text { Dealer-supplier } \\
\text { relationship }\end{array}$ & Regression analysis & Dyadic & External & $\begin{array}{l}\text { Interdependence (sum of } \\
\text { dealer dependence and } \\
\text { supplier dependence) and } \\
\text { asymmetry of } \\
\text { interdependence (the } \\
\text { absolute value of the } \\
\text { difference between dealer } \\
\text { and supplier dependence) }\end{array}$ \\
\hline $\begin{array}{l}\text { Perceived } \\
\text { dyadic data } \\
\text { collection }\end{array}$ & $\begin{array}{l}\text { (Mohr et al. } \\
1996)\end{array}$ & $\begin{array}{l}\text { Collaborative } \\
\text { communication }\end{array}$ & $\begin{array}{l}\text { Dealer-manufacturer } \\
\text { relationship }\end{array}$ & $\begin{array}{l}\text { Hierarchical moderator } \\
\text { regression } \\
\text { analysis }\end{array}$ & Dyadic & External & Scores were averaged \\
\hline $\begin{array}{l}\text { Dyadic data } \\
\text { collection }\end{array}$ & $\begin{array}{l}\text { (Blesa and } \\
\text { Bigné 2005) }\end{array}$ & $\begin{array}{l}\text { The effect of } \\
\text { market orientation } \\
\text { in dyadic } \\
\text { relationship }\end{array}$ & $\begin{array}{l}\text { Distributor- } \\
\text { manufacturer } \\
\text { relationship }\end{array}$ & SEM & Dyadic & External & NA \\
\hline $\begin{array}{l}\text { Dyadic data } \\
\text { collection }\end{array}$ & $\begin{array}{l}\text { (Bstieler et } \\
\text { al. 2017) }\end{array}$ & $\begin{array}{l}\text { Mutual trust } \\
\text { development }\end{array}$ & $\begin{array}{l}\text { University-industry } \\
\text { dyad }\end{array}$ & $\begin{array}{l}\text { SEM and multilevel } \\
\text { modeling analysis }\end{array}$ & Dyadic & External & $\begin{array}{l}\text { within each dyad, } \\
\text { observations } \\
\text { were coded ' } 1 \text { ' for } \\
\text { university and '- } 1 \text { ' for } \\
\text { company }\end{array}$ \\
\hline $\begin{array}{l}\text { Dyadic data } \\
\text { collection }\end{array}$ & $\begin{array}{l}\text { (Deshpandé } \\
\text { et al. 1993) }\end{array}$ & $\begin{array}{l}\text { Corporate culture, } \\
\text { customer, } \\
\text { orientation and }\end{array}$ & $\begin{array}{l}\text { Marketing- } \\
\text { purchasing } \\
\text { relationship }\end{array}$ & Correlation analysis & $\begin{array}{l}\text { Quadradic } \\
\text { (double dyads) }\end{array}$ & $\begin{array}{l}\text { Internal and } \\
\text { external }\end{array}$ & Calculated averages \\
\hline
\end{tabular}




\begin{tabular}{|c|c|c|c|c|c|c|c|}
\hline $\begin{array}{l}\text { Monadic/ } \\
\text { perceived } \\
\text { dyadic/ } \\
\text { dyadic data } \\
\text { collection }\end{array}$ & Paper & Theory focus & Unit of analysis & $\begin{array}{l}\text { Measurement and } \\
\text { analysis }\end{array}$ & $\begin{array}{l}\text { Monadic/dyadic / } \\
\text { network } \\
\text { conceptualization }\end{array}$ & $\begin{array}{l}\text { Internal or } \\
\text { external } \\
\text { relationship }\end{array}$ & Dyadic operationalization \\
\hline & & innovativeness & & & & & \\
\hline $\begin{array}{l}\text { Dyadic data } \\
\text { collection }\end{array}$ & $\begin{array}{l}\text { (Deshpandé } \\
\text { et al. 2000) }\end{array}$ & $\begin{array}{l}\text { Country } \\
\text { comparison of } \\
\text { high performance } \\
\text { firms }\end{array}$ & $\begin{array}{l}\text { Marketing- } \\
\text { purchasing } \\
\text { relationship }\end{array}$ & $\begin{array}{l}\text { Correlation analysis, } \\
\text { MANOVA }\end{array}$ & $\begin{array}{l}\text { Quadradic } \\
\text { (double dyads) }\end{array}$ & $\begin{array}{l}\text { Internal and } \\
\text { external }\end{array}$ & Calculated averages \\
\hline $\begin{array}{l}\text { Dyadic data } \\
\text { collection }\end{array}$ & $\begin{array}{l}\text { (DelVecchio } \\
1996)\end{array}$ & $\begin{array}{l}\text { Differences in } \\
\text { salesperson and } \\
\text { manager } \\
\text { perceptions } \\
\end{array}$ & $\begin{array}{l}\text { Salesperson and } \\
\text { manager dyad }\end{array}$ & t-test & Dyadic & Internal & NA \\
\hline $\begin{array}{l}\text { Dyadic data } \\
\text { collection }\end{array}$ & (Dyer 1996) & $\begin{array}{l}\text { Specialized } \\
\text { supplier network }\end{array}$ & $\begin{array}{l}\text { Supplier-automaker } \\
\text { relationship }\end{array}$ & t-test & $\begin{array}{l}\text { Dyadic within } \\
\text { network }\end{array}$ & External & NA \\
\hline $\begin{array}{l}\text { Dyadic data } \\
\text { collection }\end{array}$ & $\begin{array}{l}\text { (Gilliland } \\
\text { and Bello } \\
\text { 2002) }\end{array}$ & $\begin{array}{l}\text { Commitment } \\
\text { theory - Different } \\
\text { aspects of } \\
\text { attitudinal } \\
\text { commitment }\end{array}$ & $\begin{array}{l}\text { Distributor- } \\
\text { manufacturer } \\
\text { relationship }\end{array}$ & SEM & Dyadic & External & \\
\hline $\begin{array}{l}\text { Dyadic data } \\
\text { collection }\end{array}$ & (Heide 1994) & $\begin{array}{l}\text { Inter- } \\
\text { organizational } \\
\text { governance }\end{array}$ & $\begin{array}{l}\text { Manufacturer- } \\
\text { customer } \\
\text { relationship }\end{array}$ & $\begin{array}{l}\text { Literature review and } \\
\text { typology development, } \\
\text { ordinary } \\
\text { least squares regression } \\
\text { mode }\end{array}$ & Dyadic & External & $\begin{array}{l}\text { Interaction term tested in } \\
\text { the model (for } \\
\text { dependence) }\end{array}$ \\
\hline $\begin{array}{l}\text { Dyadic data } \\
\text { collection }\end{array}$ & $\begin{array}{l}\text { (Holmlund- } \\
\text { Rytkönen } \\
\text { and } \\
\text { Strandvik } \\
\text { 2005) } \\
\end{array}$ & Relationship stress & $\begin{array}{l}\text { Buyer-seller } \\
\text { relationship }\end{array}$ & $\begin{array}{l}\text { Critical incident } \\
\text { technique, t-test, linear } \\
\text { regression }\end{array}$ & Dyadic & External & NA \\
\hline $\begin{array}{l}\text { Dyadic data } \\
\text { collection }\end{array}$ & $\begin{array}{l}\text { (Johnston } \\
\text { and Bonoma } \\
\text { 1981) }\end{array}$ & $\begin{array}{l}\text { Structure and } \\
\text { interaction } \\
\text { patterns of buying } \\
\text { center }\end{array}$ & Buying center & Regression analysis & $\begin{array}{l}\text { Dyadic and } \\
\text { network }\end{array}$ & $\begin{array}{l}\text { Internal and } \\
\text { external }\end{array}$ & Averages \\
\hline $\begin{array}{l}\text { Dyadic data } \\
\text { collection }\end{array}$ & (Joshi 2009) & $\begin{array}{l}\text { Supplier } \\
\text { performance } \\
\text { improvement }\end{array}$ & $\begin{array}{l}\text { Manufacturer- } \\
\text { supplier dyad }\end{array}$ & $\begin{array}{l}\text { Multivariate Data } \\
\text { Analysis }\end{array}$ & Dyadic & External & NA \\
\hline $\begin{array}{l}\text { Dyadic data } \\
\text { collection }\end{array}$ & $\begin{array}{l}\text { (Klein et al. } \\
\text { 2007) }\end{array}$ & $\begin{array}{l}\text { Competitive and } \\
\text { cooperative } \\
\text { positioning }\end{array}$ & Client-vendor dyad & $\begin{array}{l}\text { Partial least squares } \\
\text { (PLS) }\end{array}$ & Dyadic & External & $\begin{array}{l}\text { Degree, symmetry and } \\
\text { degree-symmetry value* }\end{array}$ \\
\hline Dyadic data & (Kumar et al. & Impact of & Supplier- & PLS & Dyadic & External & NA \\
\hline
\end{tabular}




\begin{tabular}{|c|c|c|c|c|c|c|c|}
\hline $\begin{array}{l}\text { Monadic/ } \\
\text { perceived } \\
\text { dyadic/ } \\
\text { dyadic data } \\
\text { collection }\end{array}$ & Paper & Theory focus & Unit of analysis & $\begin{array}{l}\text { Measurement and } \\
\text { analysis }\end{array}$ & $\begin{array}{l}\text { Monadic/ dyadic / } \\
\text { network } \\
\text { conceptualization }\end{array}$ & $\begin{array}{l}\text { Internal or } \\
\text { external } \\
\text { relationship }\end{array}$ & Dyadic operationalization \\
\hline collection & 2011) & $\begin{array}{l}\text { governance } \\
\text { regimes }\end{array}$ & $\begin{array}{l}\text { manufacturer } \\
\text { relationship }\end{array}$ & & & & \\
\hline $\begin{array}{l}\text { Dyadic data } \\
\text { collection }\end{array}$ & $\begin{array}{l}\text { (Palmatier et } \\
\text { al. 2007) }\end{array}$ & Customer loyalty & $\begin{array}{l}\text { Buyer-salesperson } \\
\text { dyad }\end{array}$ & SEM & Triadic & $\begin{array}{l}\text { External and } \\
\text { internal }\end{array}$ & NA \\
\hline $\begin{array}{l}\text { Dyadic data } \\
\text { collection }\end{array}$ & $\begin{array}{l}\text { (Rodriguez } \\
\text { and Wilson } \\
\text { 2002) }\end{array}$ & $\begin{array}{l}\text { Relationship } \\
\text { bonding and trust } \\
\text { as a } \\
\text { foundation for } \\
\text { commitment }\end{array}$ & $\begin{array}{l}\text { Relationship } \\
\text { between managers in } \\
\text { strategic alliances }\end{array}$ & $\begin{array}{l}\text { SEM, tested two parties } \\
\text { differences }\end{array}$ & Dyadic & External & NA \\
\hline $\begin{array}{l}\text { Dyadic data } \\
\text { collection }\end{array}$ & $\begin{array}{l}\text { (Straub et al. } \\
2004)\end{array}$ & $\begin{array}{l}\text { Firm performance } \\
\text { at the network } \\
\text { level }\end{array}$ & Client-vendor dyad & $\begin{array}{l}\text { Partial least squares } \\
\text { (PLS) }\end{array}$ & Dyadic, network & External & $\begin{array}{l}\text { Degree, symmetry and } \\
\text { degree-symmetry value* }\end{array}$ \\
\hline $\begin{array}{l}\text { Dyadic data } \\
\text { collection }\end{array}$ & $\begin{array}{l}\text { (Svensson } \\
2004 \text { ) }\end{array}$ & $\begin{array}{l}\text { Interactive } \\
\text { vulnerability }\end{array}$ & $\begin{array}{l}\text { Buyer-seller } \\
\text { relationship }\end{array}$ & t-test & Dyadic & External & NA \\
\hline $\begin{array}{l}\text { Dyadic data } \\
\text { collection }\end{array}$ & $\begin{array}{l}\text { (Whipple et } \\
\text { al. 2015) }\end{array}$ & $\begin{array}{l}\text { Collaborative } \\
\text { competence, } \\
\text { social capital, and } \\
\text { performance }\end{array}$ & $\begin{array}{l}\text { Buyer-supplier } \\
\text { relationship }\end{array}$ & SEM & Dyadic & External & NA \\
\hline $\begin{array}{l}\text { Dyadic data } \\
\text { collection }\end{array}$ & Our study & $\begin{array}{l}\text { Marketing- } \\
\text { purchasing } \\
\text { collaboration }\end{array}$ & Business relationship & $\begin{array}{l}\text { SEM and alternative } \\
\text { model comparisons }\end{array}$ & Dyadic & Internal & $\begin{array}{l}\text { Dyadic value and dyadic } \\
\text { asymmetry }\end{array}$ \\
\hline
\end{tabular}

Note: $*$ Score of party $1=\mathrm{C} 1$

Score of party $2=\mathrm{C}_{-}^{-} 2$

Degree Value $=\mathrm{C}$ DV $=\left(\begin{array}{lll}\mathrm{C} & 1+\mathrm{C} & 2\end{array}\right) / 2$

Symmetry Value $=\mathrm{C} \_\mathrm{SV}=\overline{\mathrm{I} f} \mathrm{C} \_1 \geq \mathrm{C} \_2$ then $\mathrm{C} \_\mathrm{SV}=\mathrm{C} \_2 / \mathrm{C} \_1$; or If C_ $1<\mathrm{C} \_2$ then $\mathrm{C} \_\mathrm{SV}=\mathrm{C} \_1 / \mathrm{C} \_2$

Degree-Symmetry Value $=$ C_DS $=\left(C_{-}-D V+C \_-S V\right) / 2$ 
Customer orientation (based on Narver and Slater (1990))

Measured on a five-point Likert scale anchored in 'completely disagree (1); completely agree (5)'

- We closely monitor and assess our level of commitment in serving customer's needs.

- Business strategies are driven by the goal of increasing customer value.

- Our business objectives are driven by customer satisfaction.

\section{Marketing-purchasing interaction (based on Kahn and Mentzer (1998))}

Measured on a five-point Likert scale anchored in 'completely disagree (1); completely agree (5)'

My department frequently interacts with another department [marketing or purchasing accordingly] in regards to the below activities:

- Meetings

- Committees/Task forces

- Phone conversations

- Emails

Marketing-purchasing collaboration (based on Kahn and Mentzer (1998))

Measured on a five-point Likert scale anchored in 'completely disagree (1); completely agree (5)'

Marketing and purchasing departments...

- Achieve goals collectively

- Have a mutual understanding

- Share ideas, information and/or resources

- Work together as a team

Business performance (based on Vorhies and Harker (2000))

Measured on five-point bi-polar scales, and anchored in 'much worse (-2); much better (2)', asking the respondents to compare their own business performance with that of competitors

- Growth of comparative market share

- Sales growth

- Business profitability 